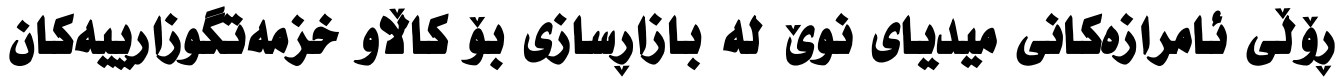

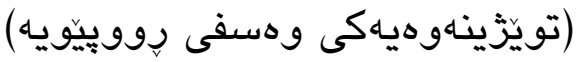

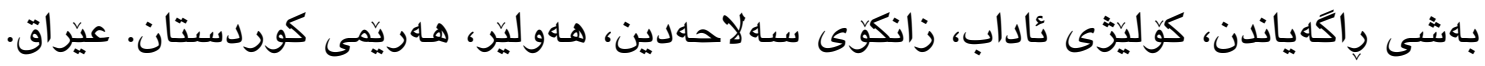

يّلهروا عمر محمود

perwa.umer@yahoo.com

كيمهايل:

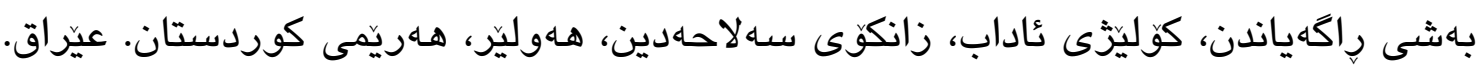

هلهردوان محمود كاكهشيخخ

hardawan@su.edu.krd

تيمهيل:

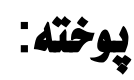

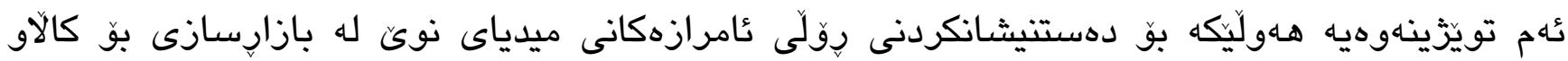

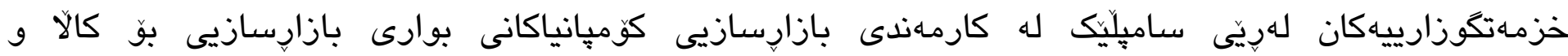

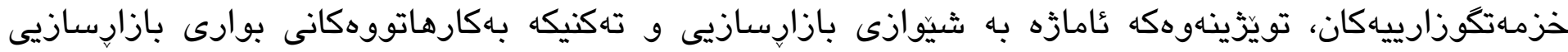

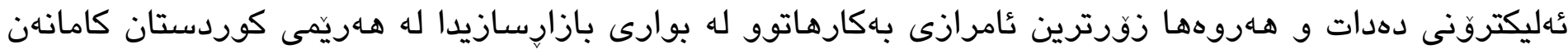
دهستنيشان دهكات.

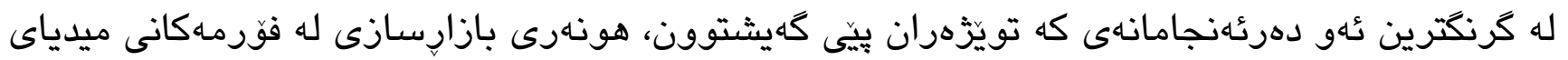

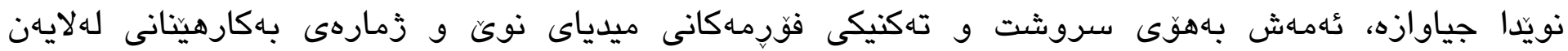

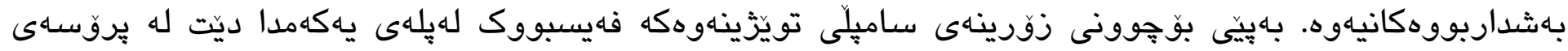

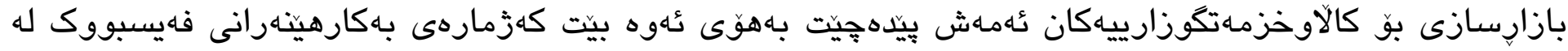

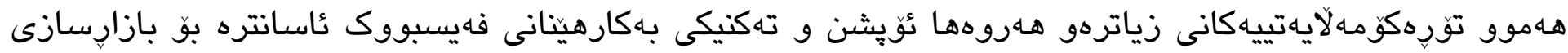

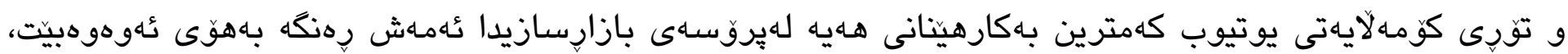

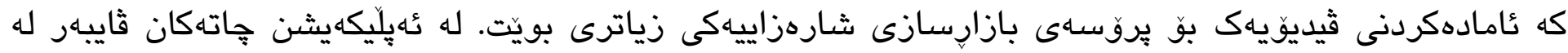

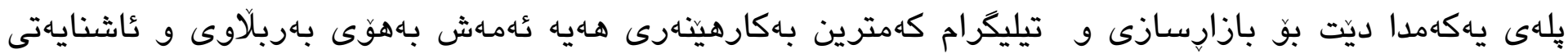

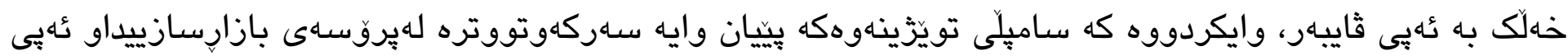

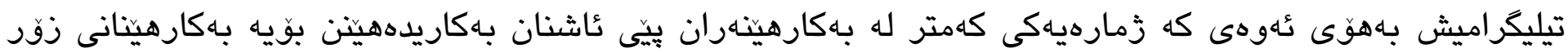




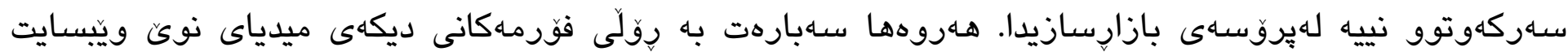

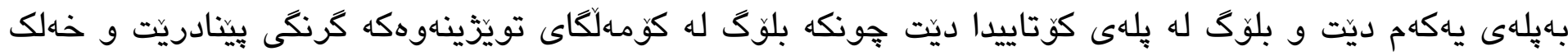
زانياريان لهبارهياوه نييه.

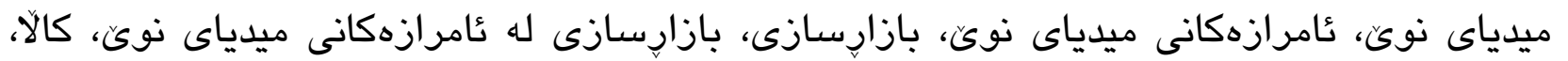

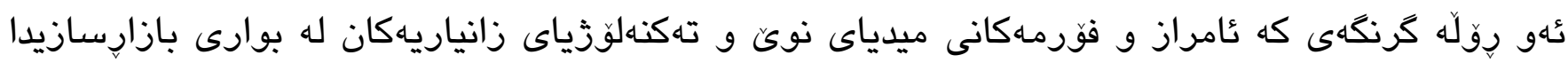

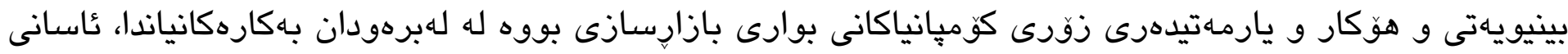

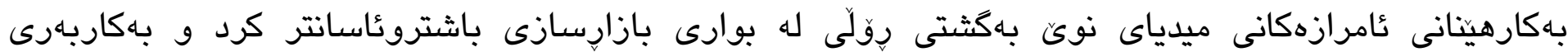

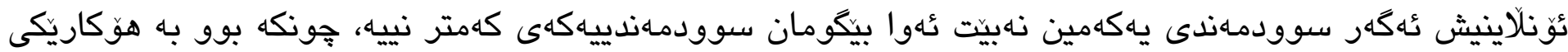

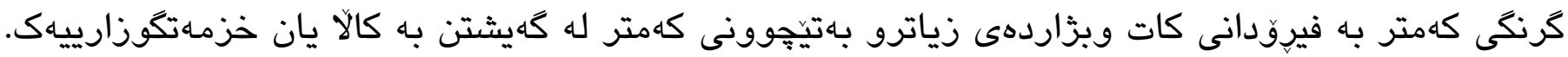

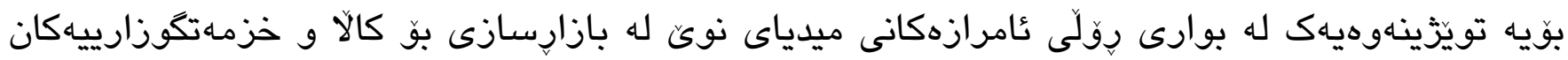

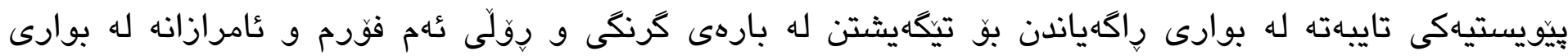
بازارسازيدا.

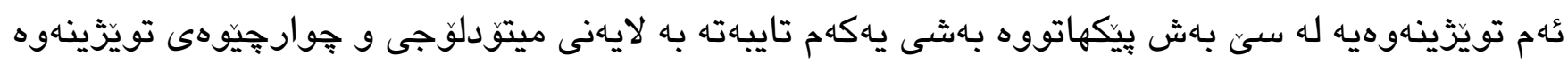

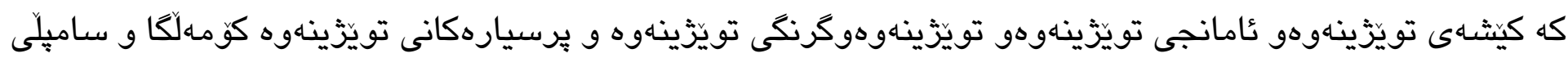

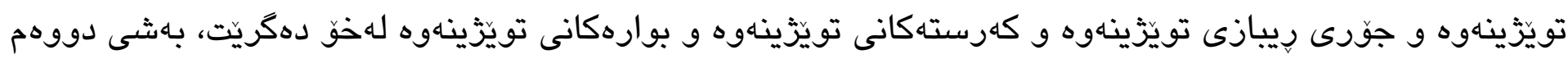

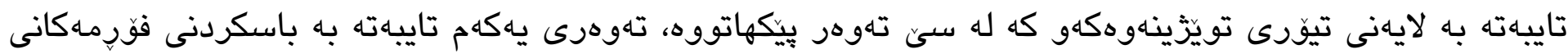

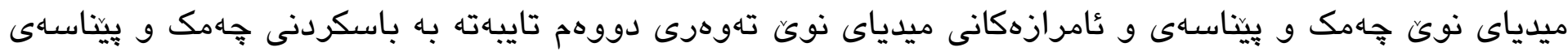

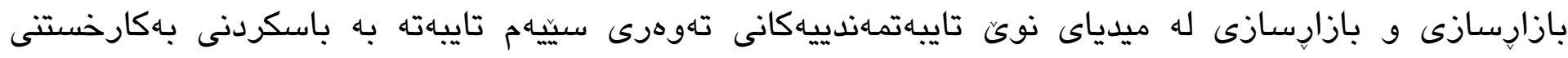

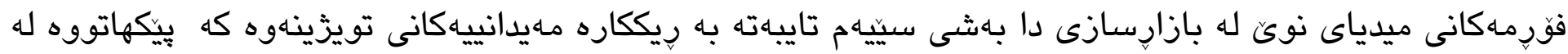

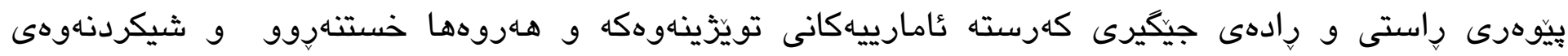

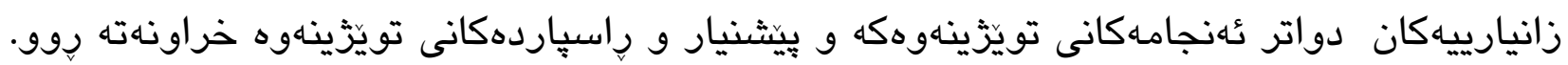




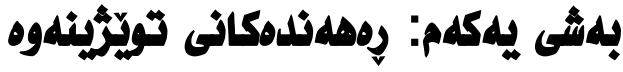

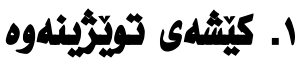

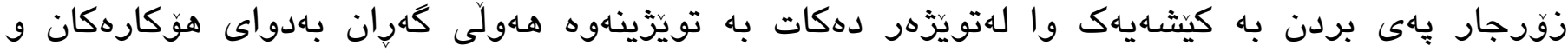

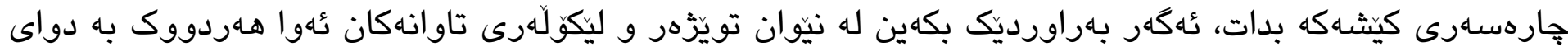

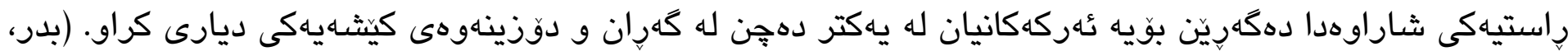
$(T r, r \cdot 1 \varepsilon$

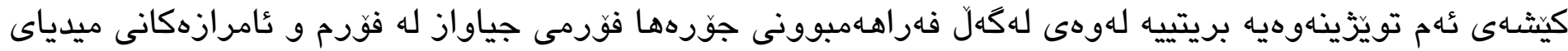

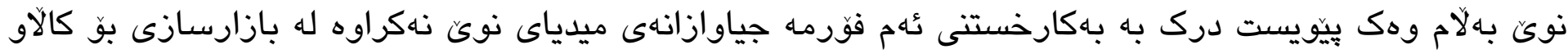

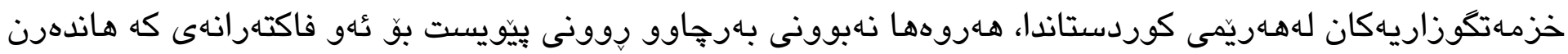

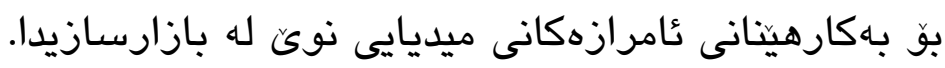

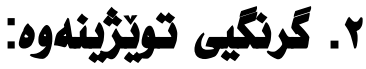

كرنكيى ئهم تويَزّينهوهيه لهم خالآنهى خوارهوهدا دهيينينهوه:

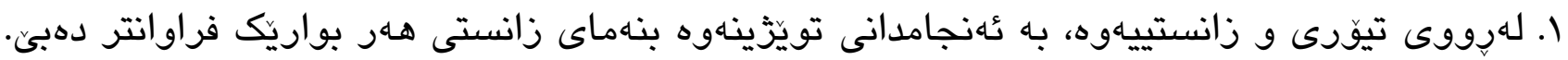

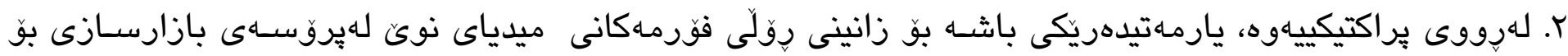

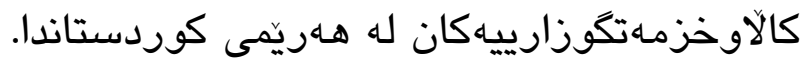

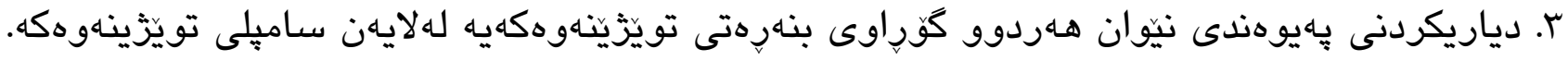

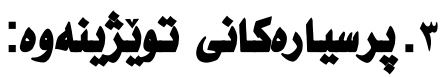

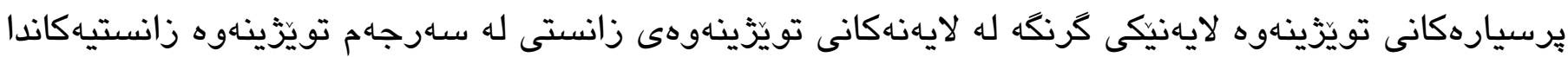

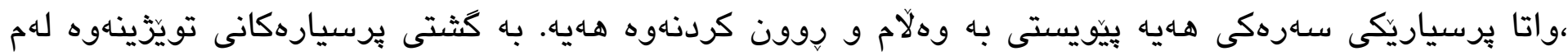

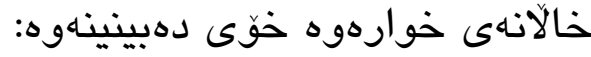

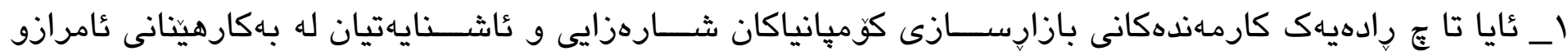

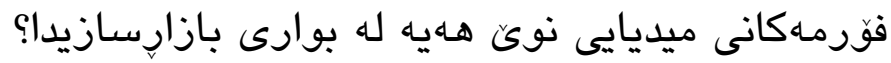

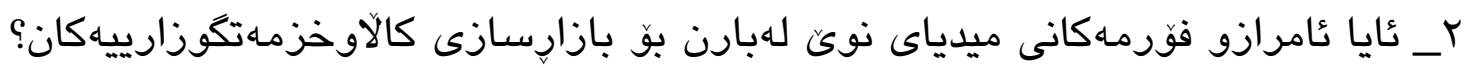

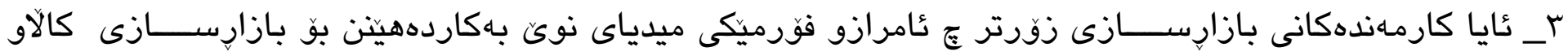

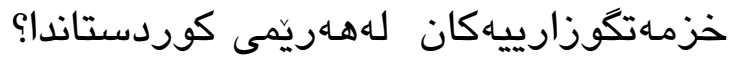




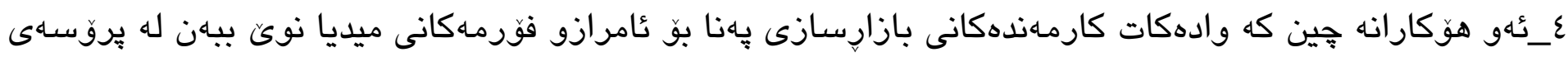

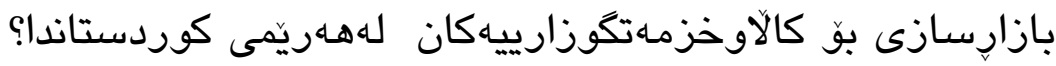

ع. تُامانجهكاذى تُوِّرِينهوه:

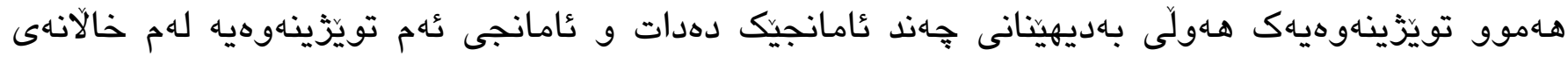
خوارهوهدا خوّى دهبينيتهاهوه: أ-ناساندنى عَامرازو فورمهـكانى ميدياى نوىّ.

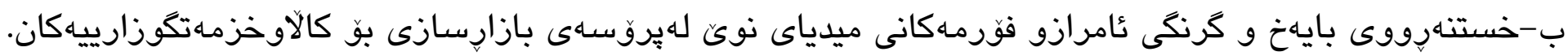

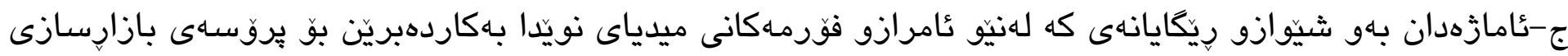

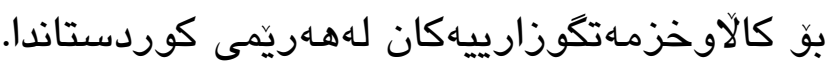

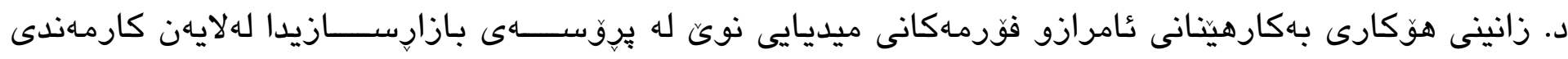
بازارسازى كوميانياكانى بوارى بازارسازى له هـاريّمى كوردستاندا.

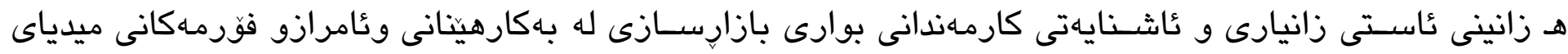
نوىن له هـاهيميى كوردستاندا.

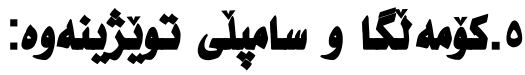

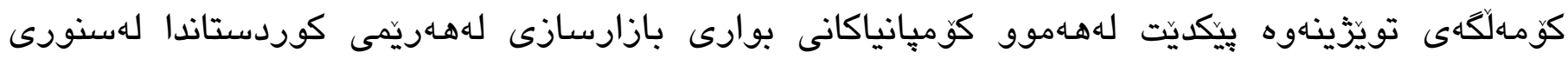

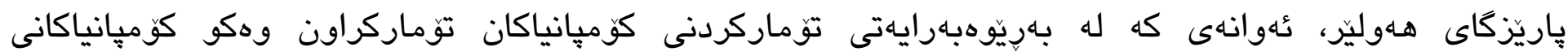
mall,،lucid,next fly,elegent,aposttroph, electronic)

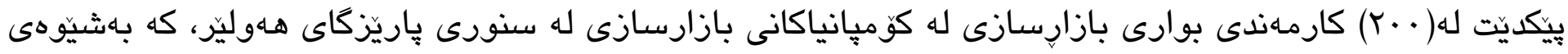

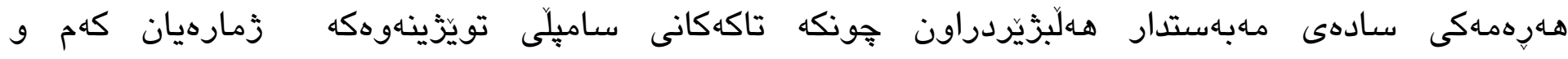
هاوكوفن(متجانس)ن.

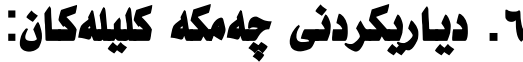

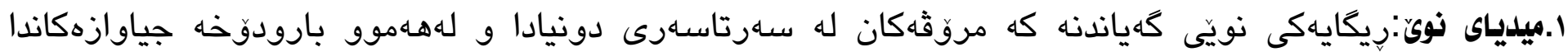

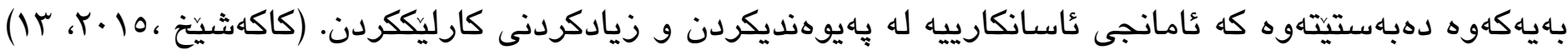

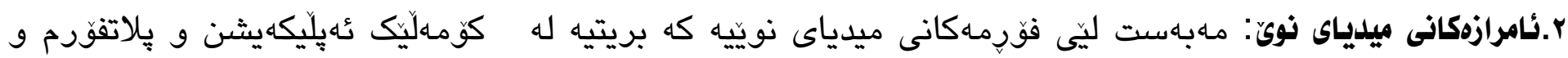

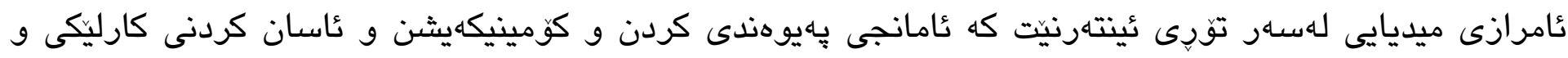

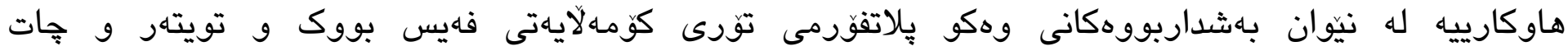

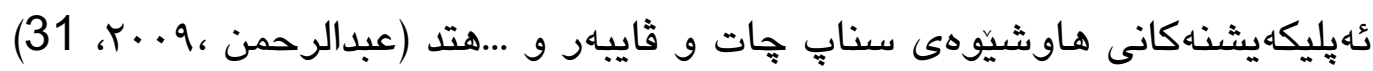




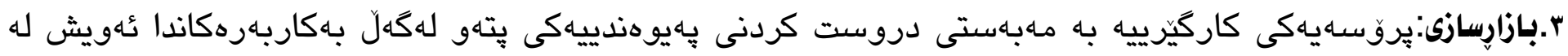

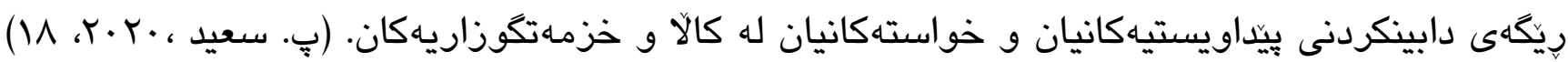

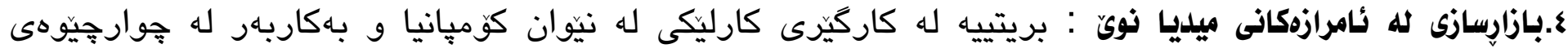

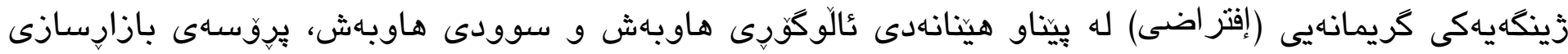

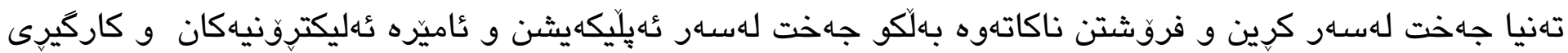

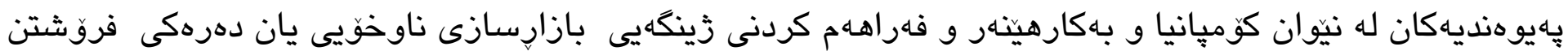

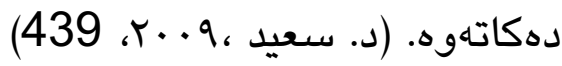

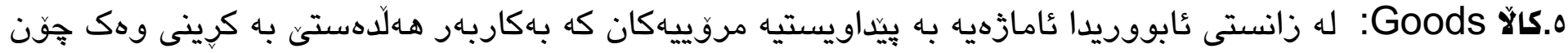

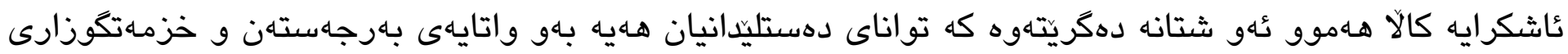

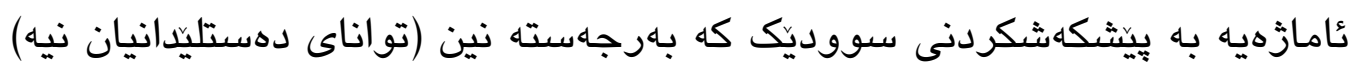
7.خزمهتكوزارى Service : بازارسازى خزمهتكوزارى له ئيستادا كرنكيهكهى زيادى كردووه كه بهكثتى بريتيه له

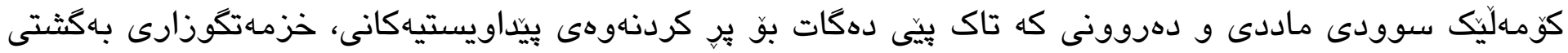

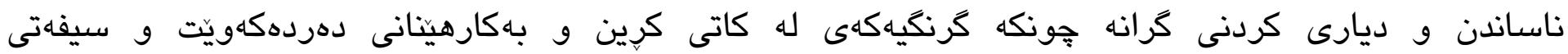

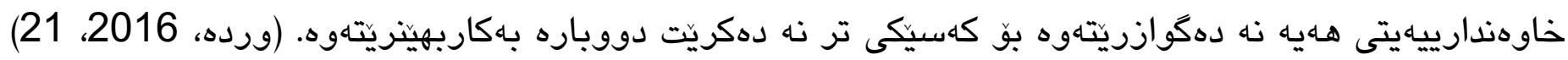

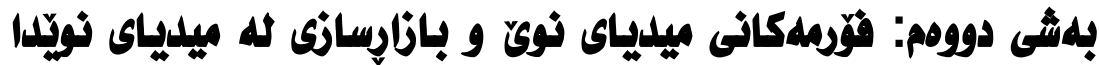
تلوورى يلهكلم: ميلياى ثوى و تايبلاتمهنلييلكافى يليكلم:ميلياى نوى (New media)

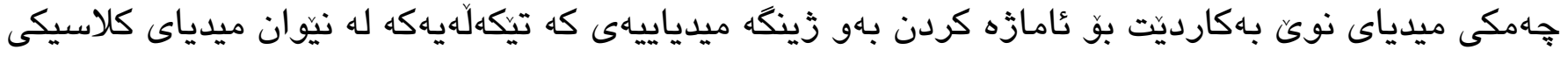
تهلهذزيون و راديو و روّزنامه له له لايهك و ميديايى زمارهيى له لايهكى تر بهتايبهت ميدياى كارليكى و ميدياى

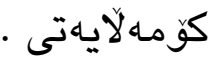

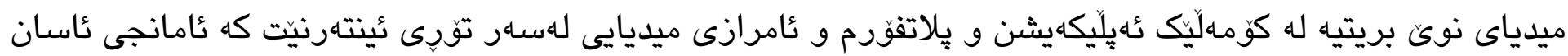

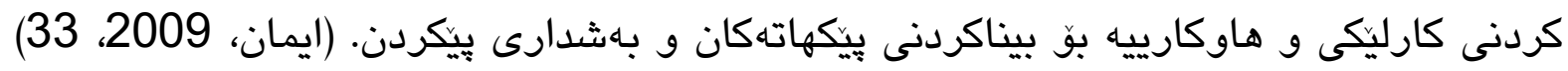

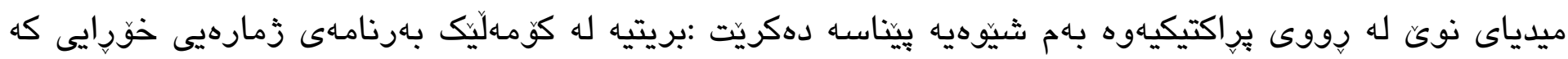

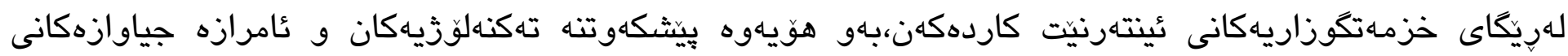

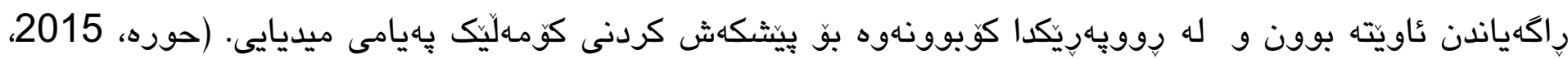




\section{دووم:تخايبهتهلنلييهكانى ميدياى نوى:}

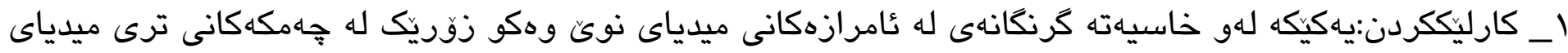

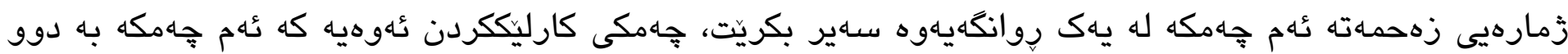

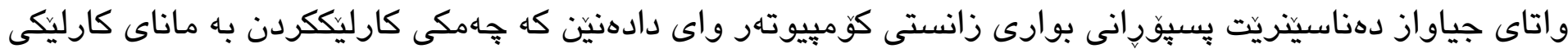

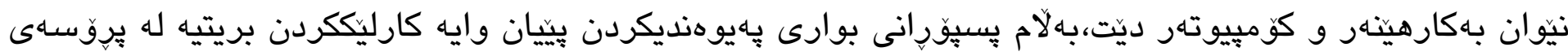

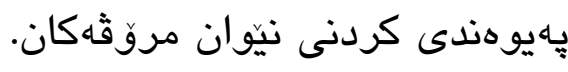

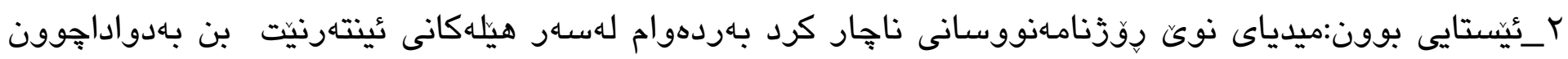

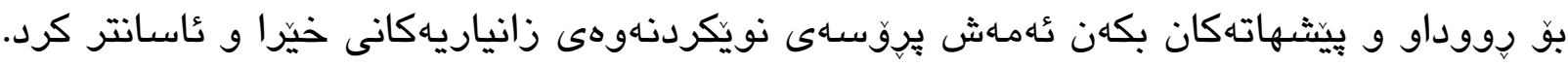

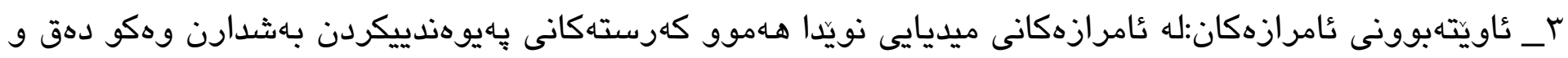

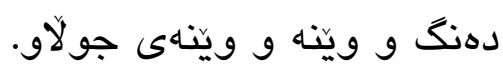

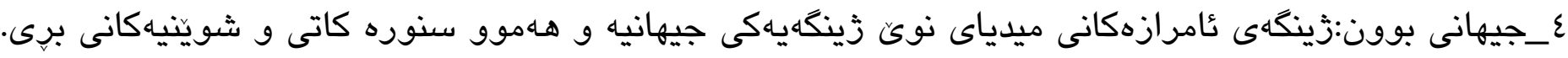

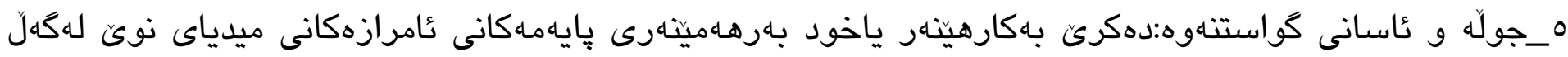

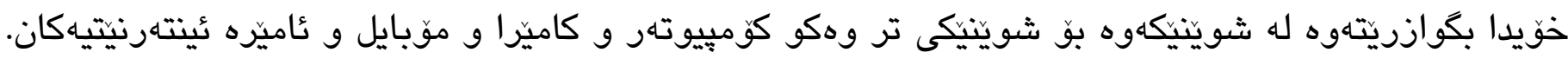

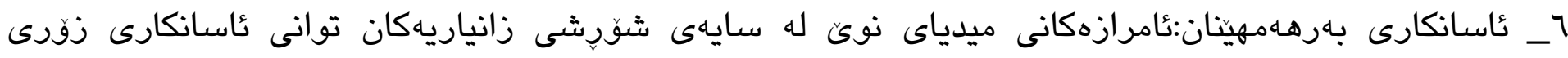

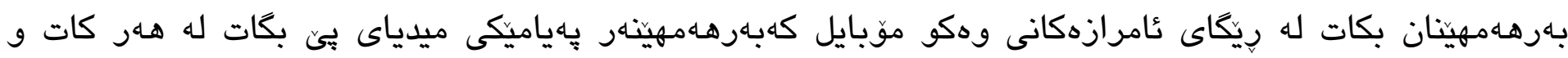
بارودوخيكدا بيتي.

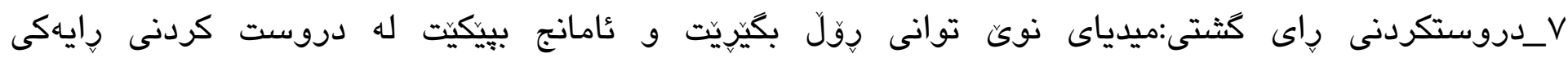

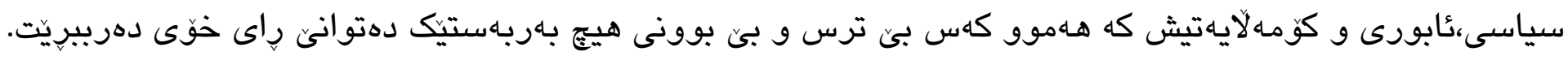

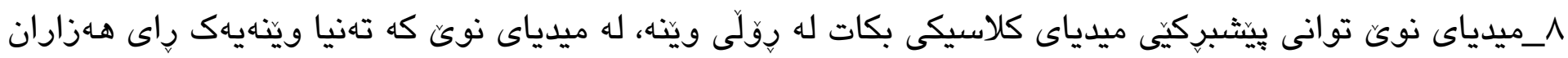

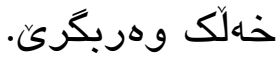

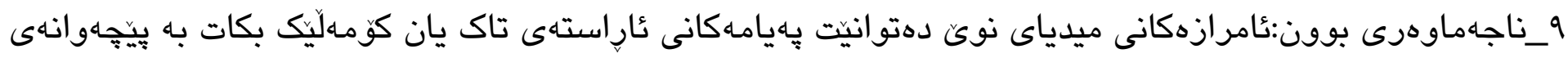

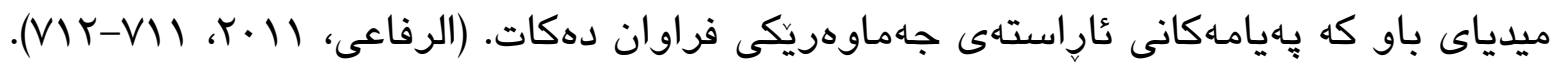




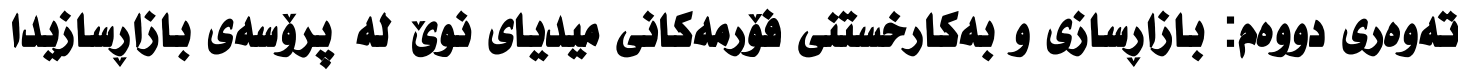

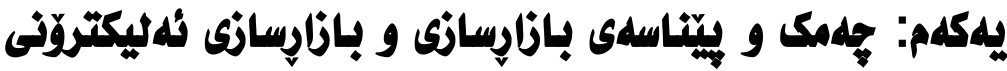

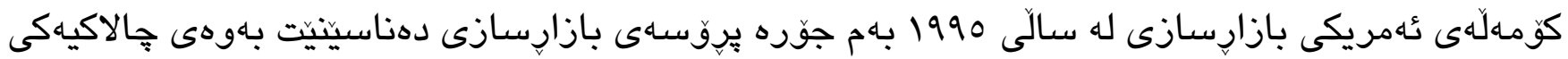

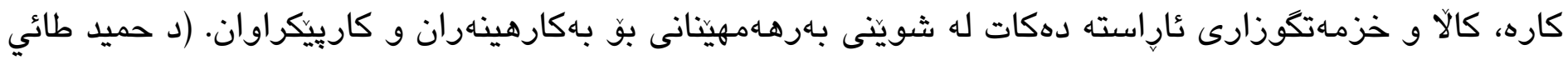
$(V, r \cdots O$.

دواتركومهلّهى ئهريكى له سـالَى 2003 يِيناسـيهكى نويّى بوّ بازارسازى دارشت بهوهى كه بازارسازى بريتيه له

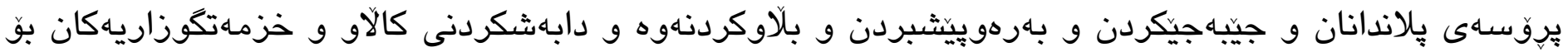

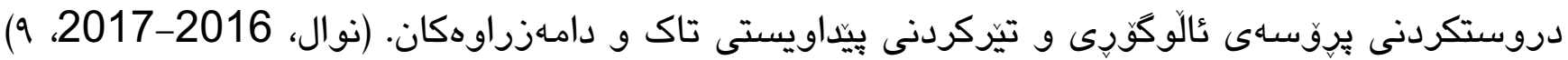

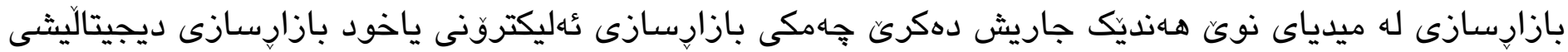

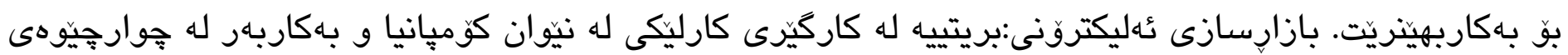

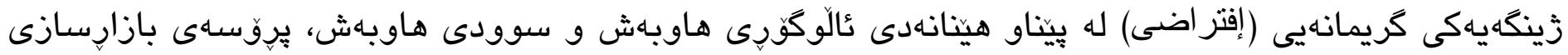

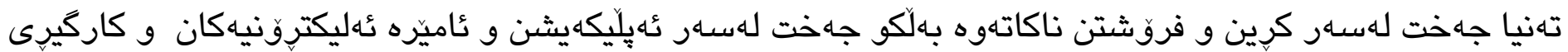

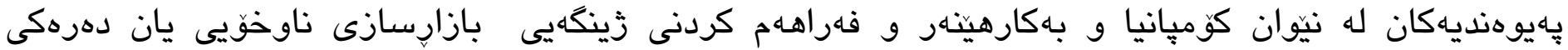

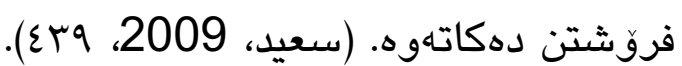

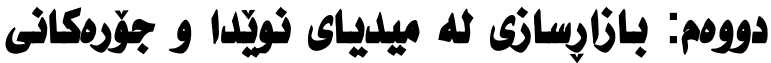

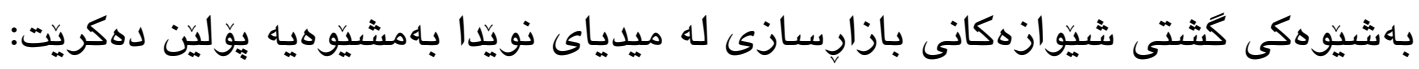

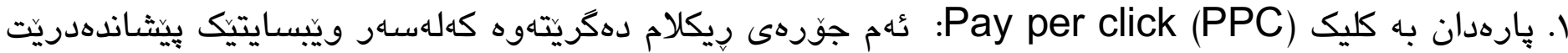

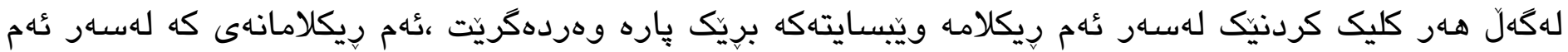

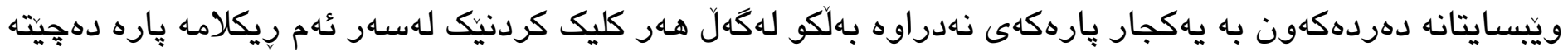

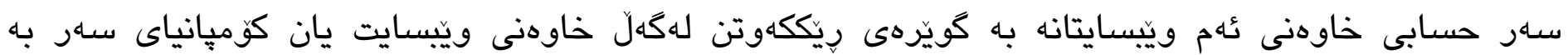

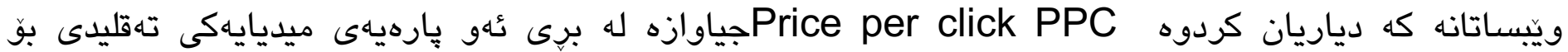

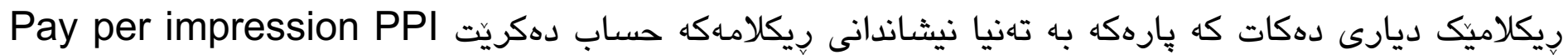

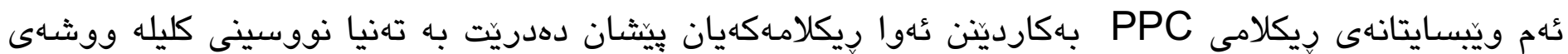

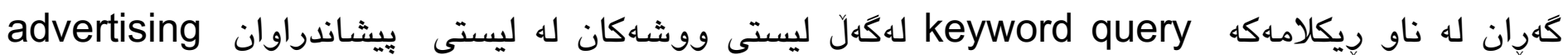

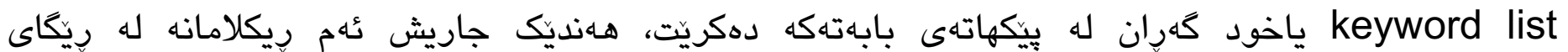

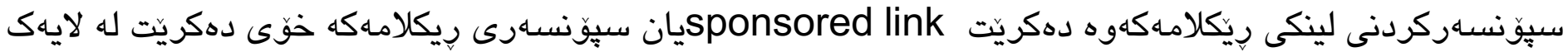

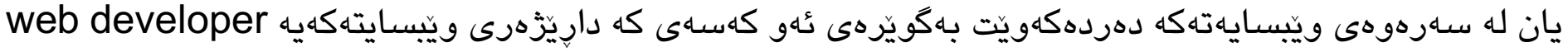




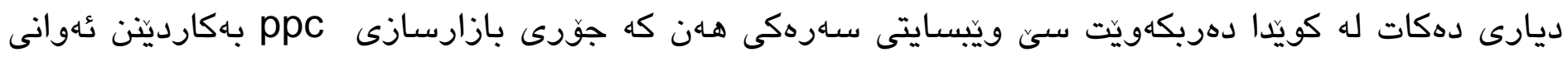

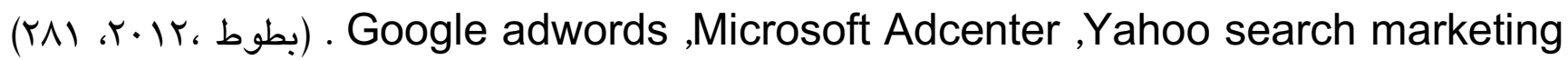

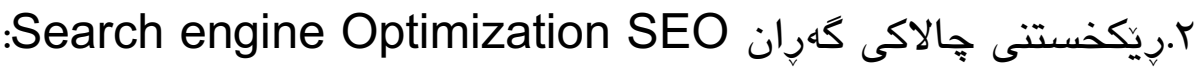

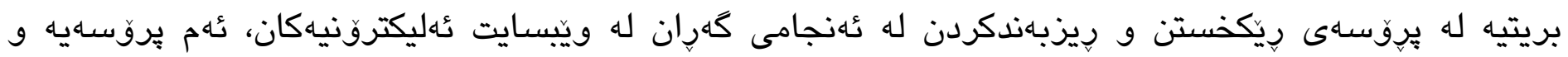

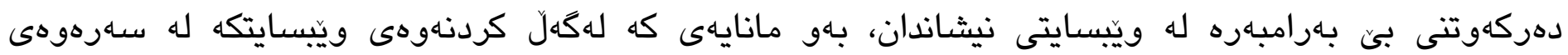

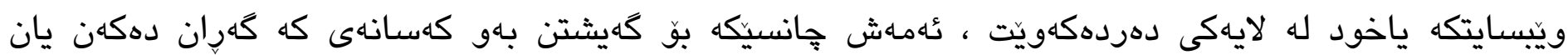

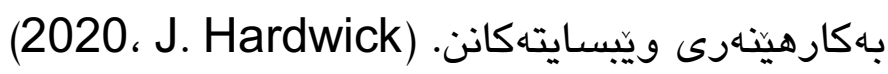

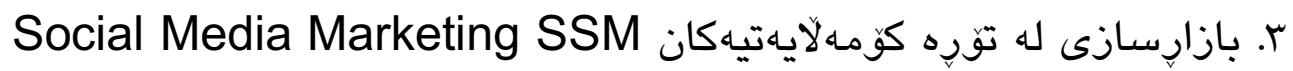

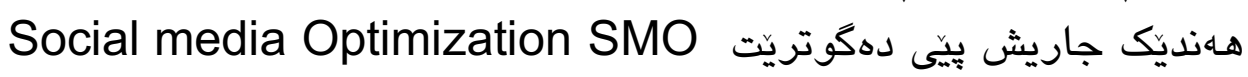

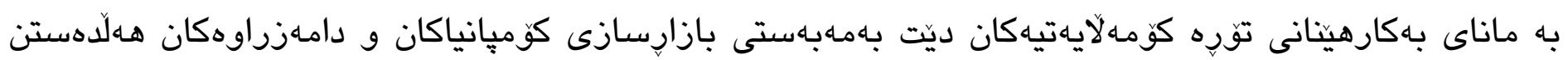

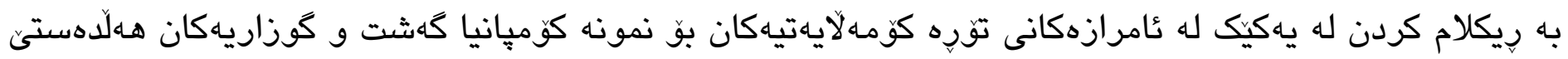

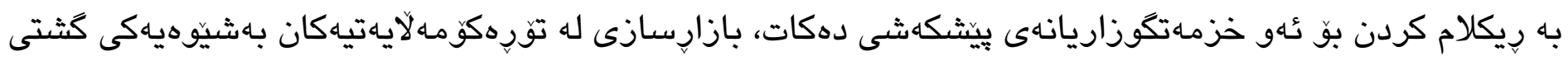

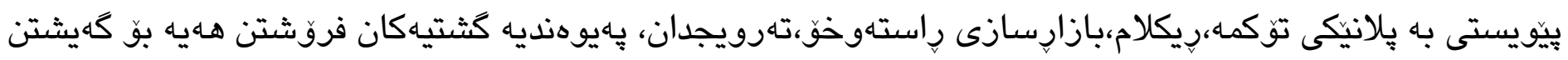

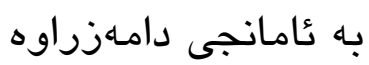

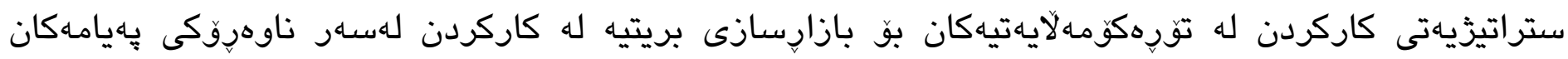

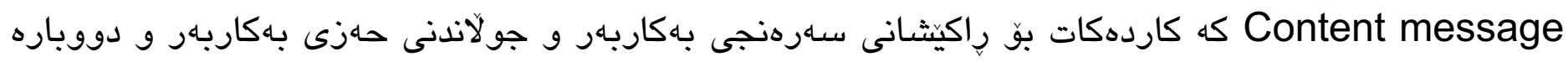

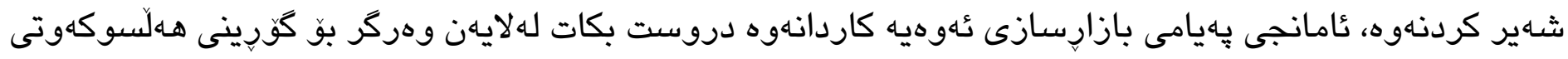

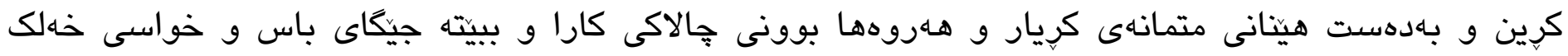

Word of mouth adverting

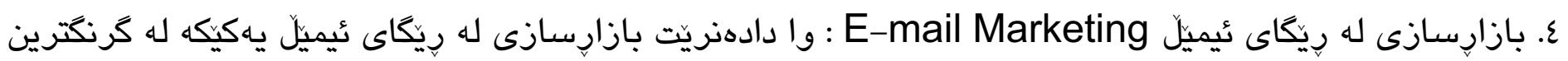

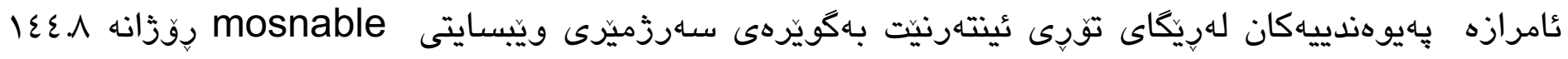

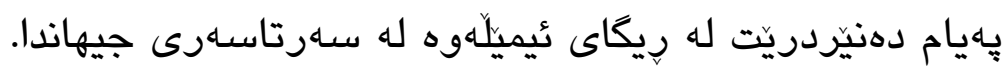

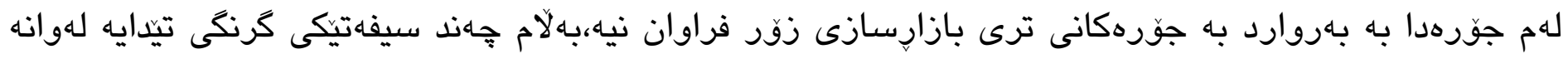

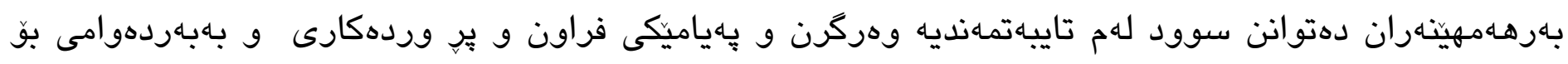

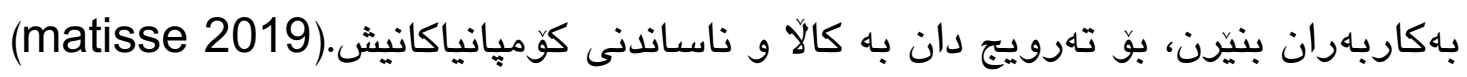

Content Marketing بـ بازارسازى ناوهروك

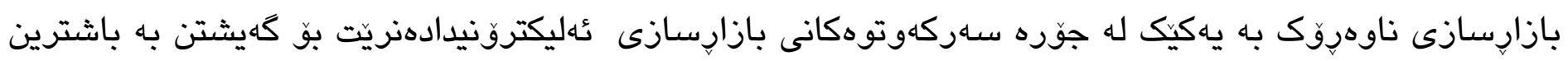

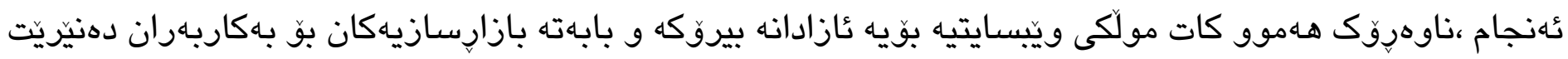

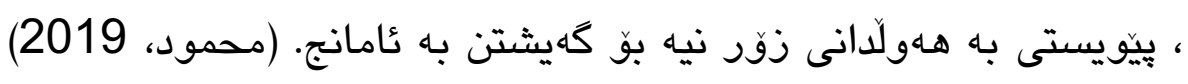

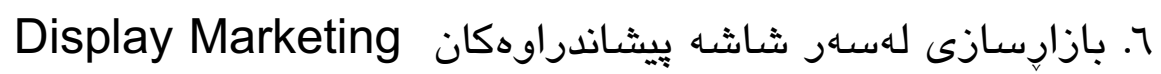




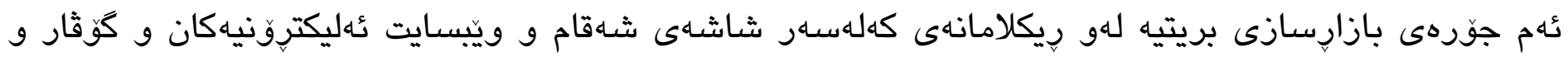

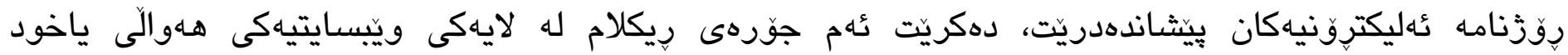

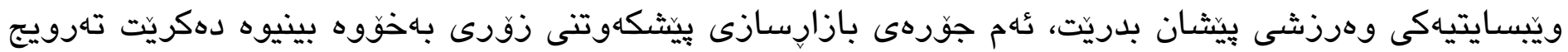

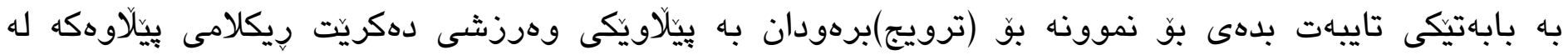

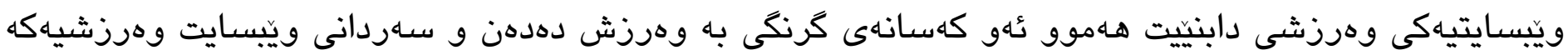

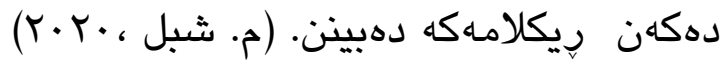

Paid Advertising Marketing بازارسازى له رِيَّاى رِيكلامى يارهيى.V

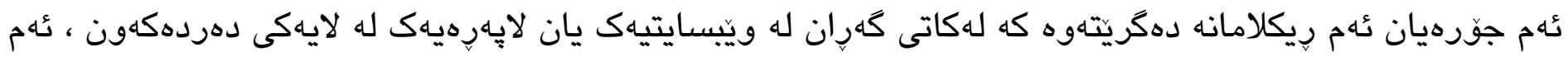

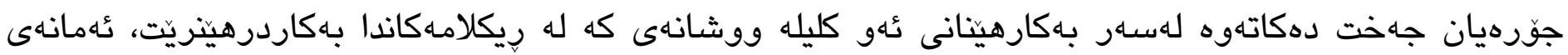

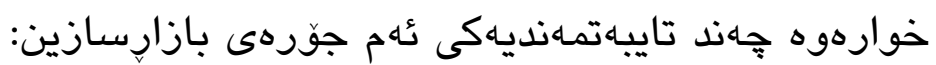

\section{كُهنجامى خيرا}

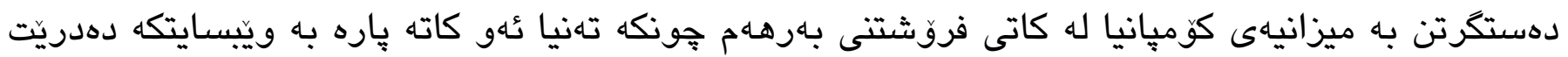

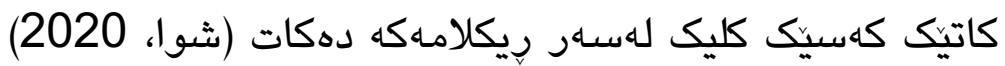

Mobile Marketing بـازارسازى له رِيَّاى موّبايل

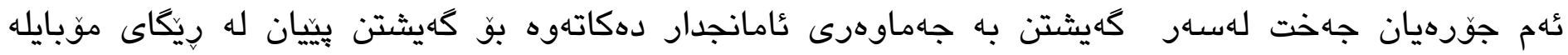

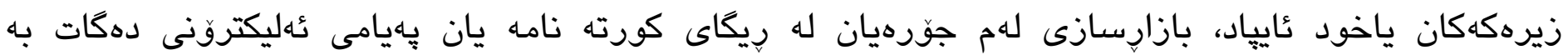

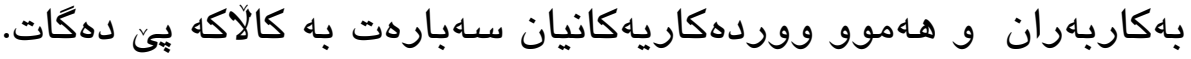

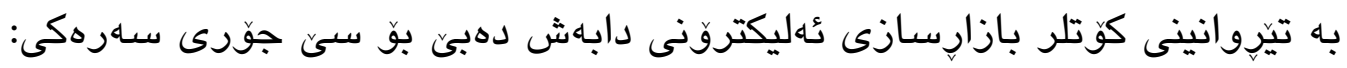
ا.بازارِسازى دهرهكى :عxternal Marketing :ُهم جورهيان بهستراوهتهوه بـه بنهما تهقليدييهكانى بازارسازى

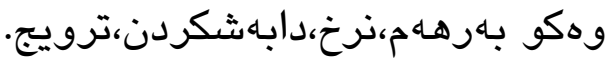

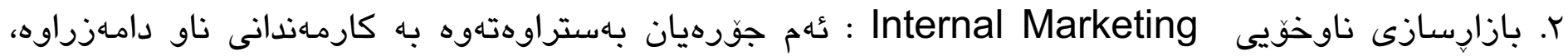

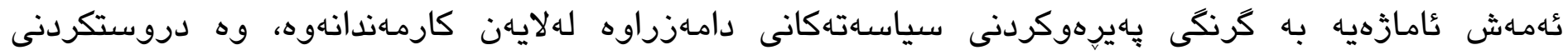

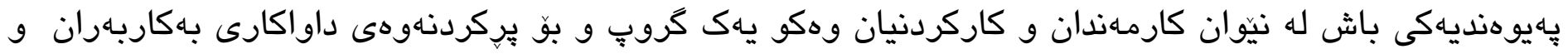

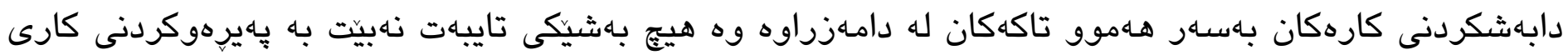
بازارى تإهليدى.

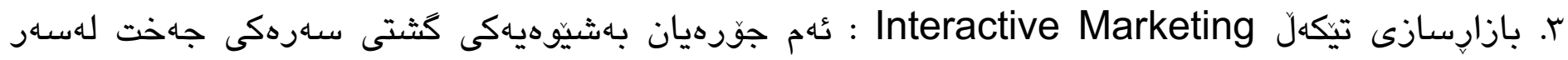

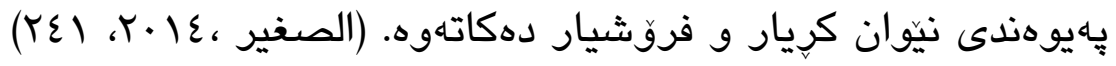


ههروهها بازارسازى له ميدياى نويدا له رههندى تيجهوونهوه(Cost) جهند جوّريكه:

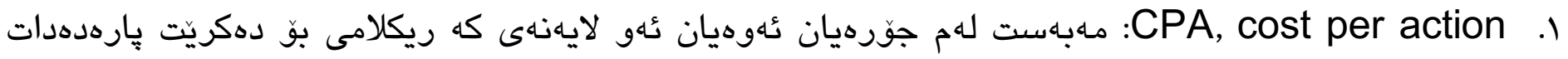

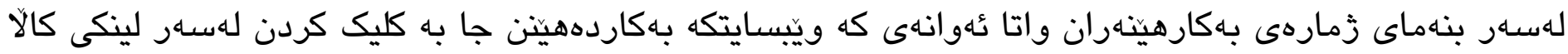

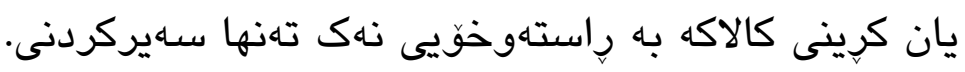

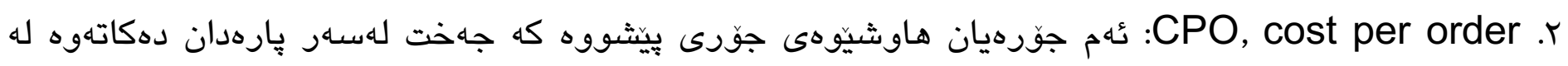

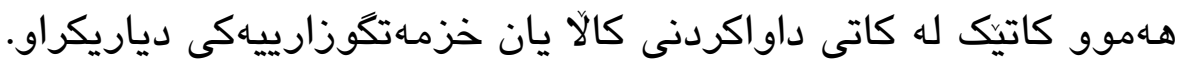

r.

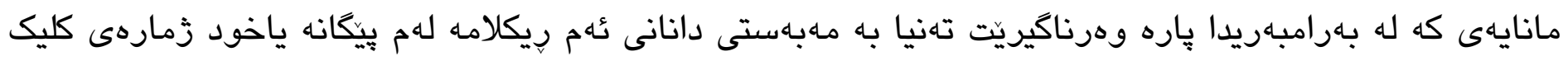

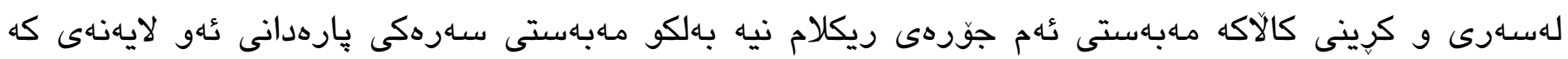

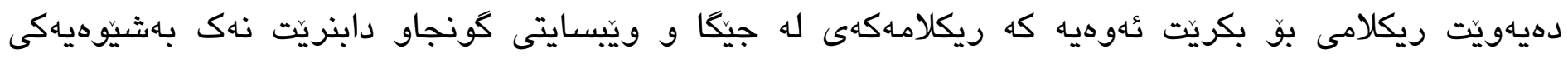
هـاردماككى.

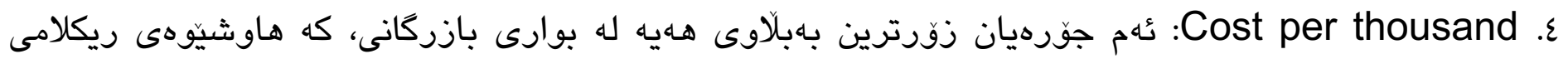

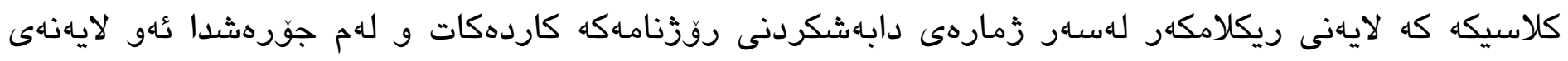

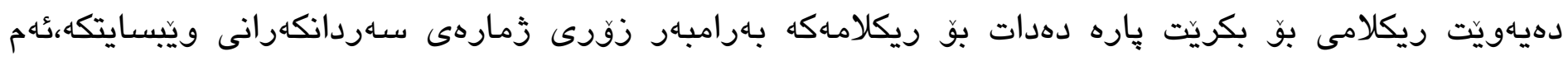

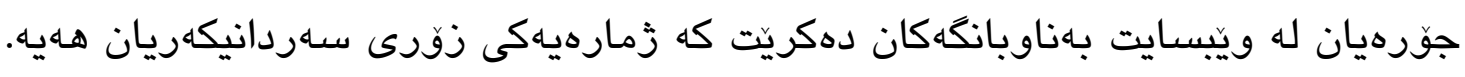

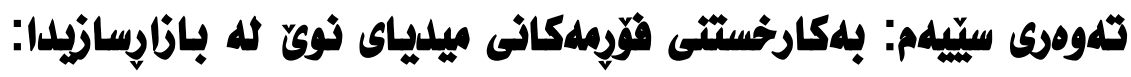

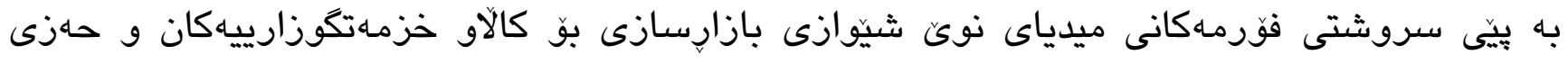

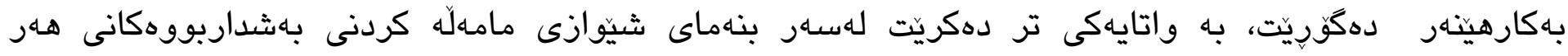

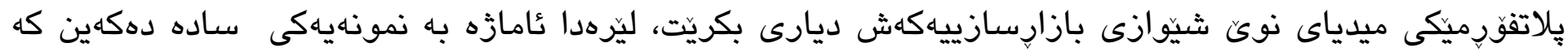

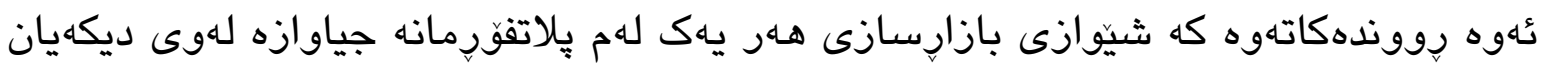


(1) ويناهى (1)

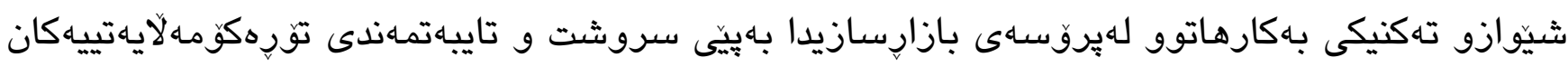
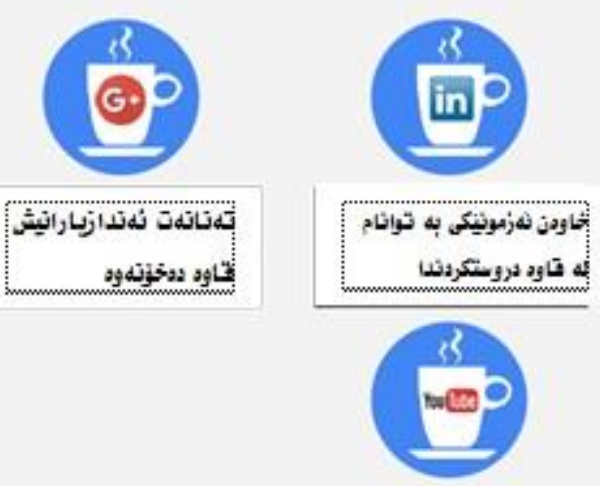

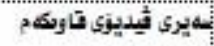

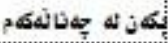

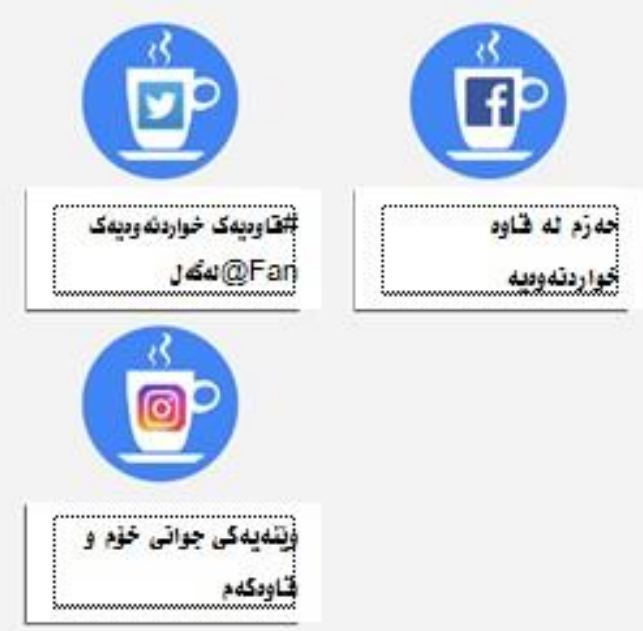

له ويناهى (1) وهك (1) (1)

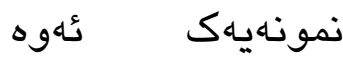

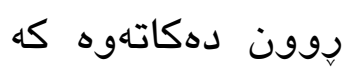

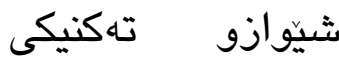
بهارهاتوو

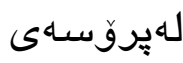

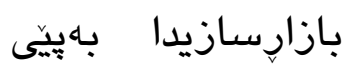
سروشت

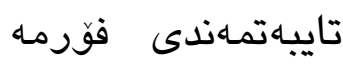

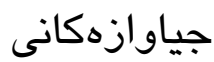

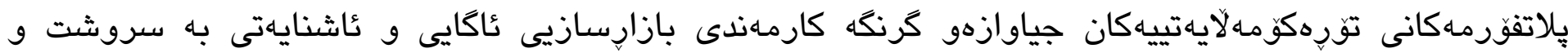

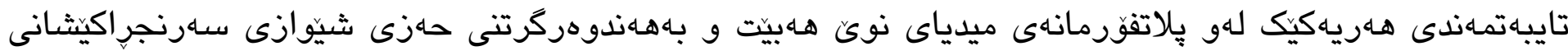

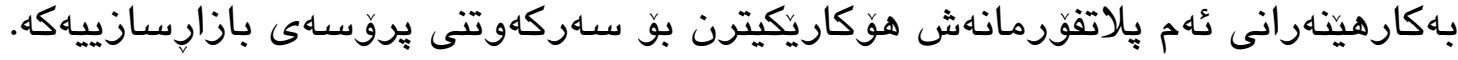

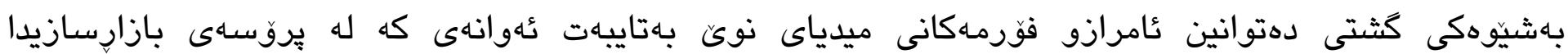

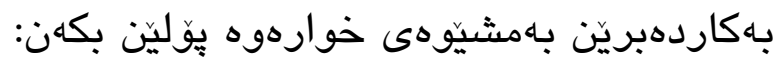

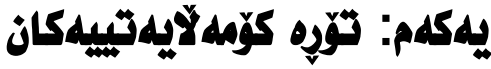

ا. ثليسبورك Facebook:هـنديك سيفهتى هـيه كه بازابسازى تييدا ئاسانه لهوانه:

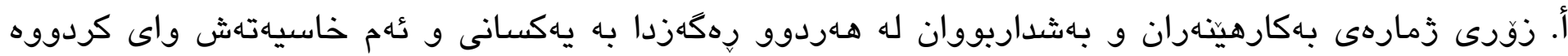

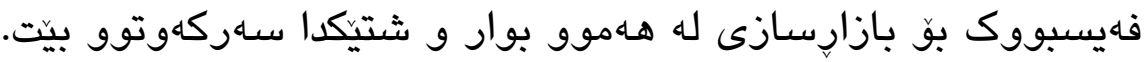

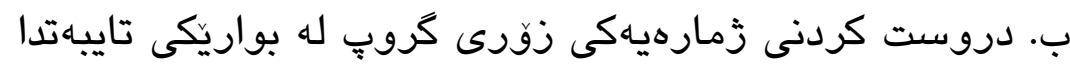

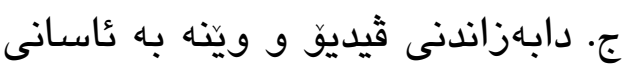

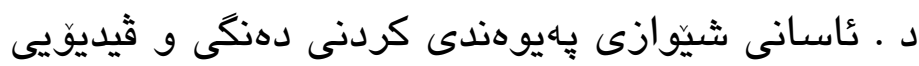

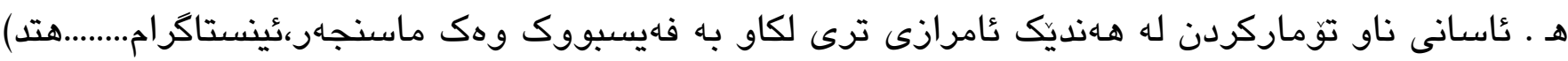

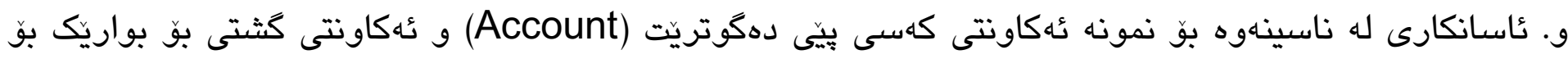

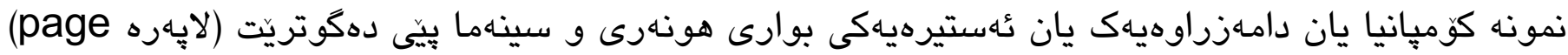

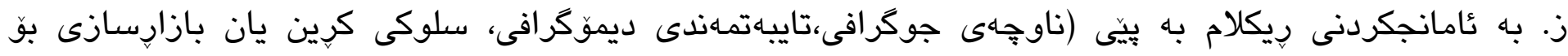

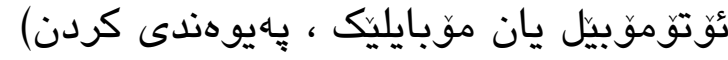

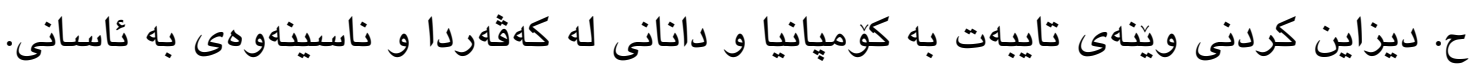




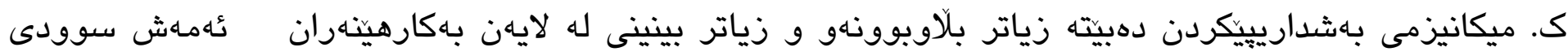

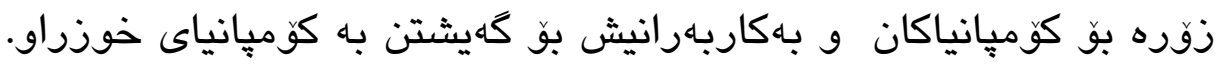

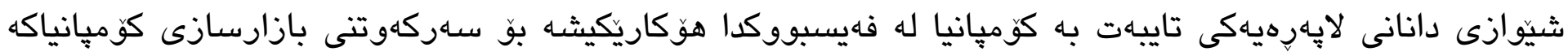
لهوانه:

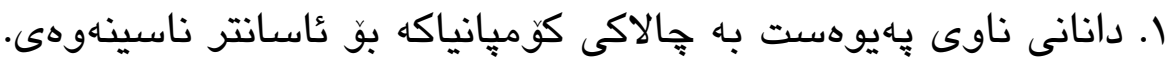

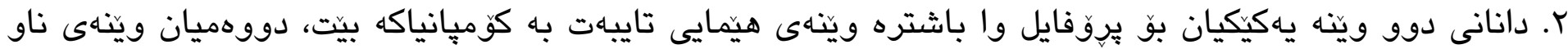

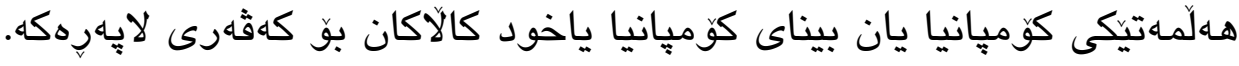

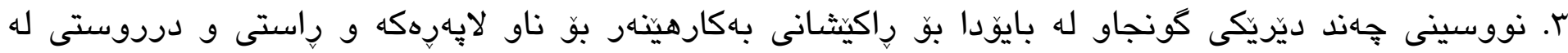
زانياريـكان.

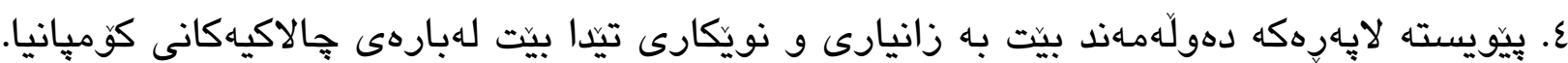

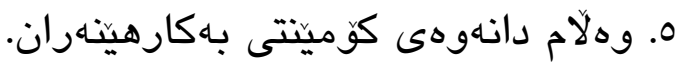

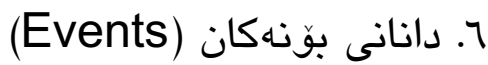

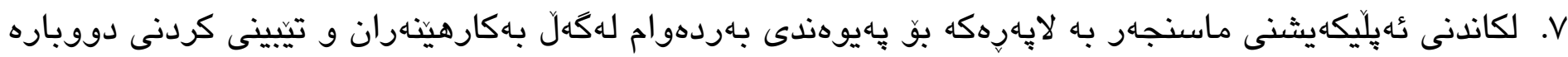
بوونهوهى يرسيارهكانيان.

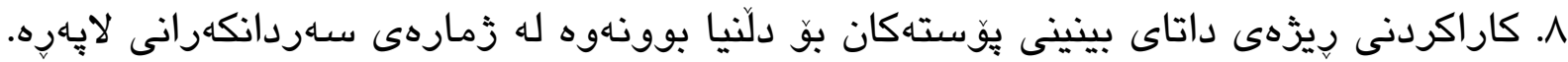

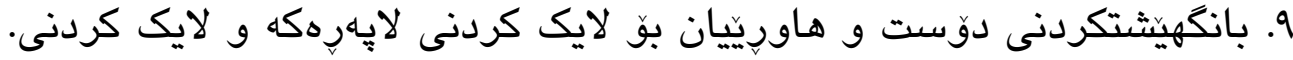

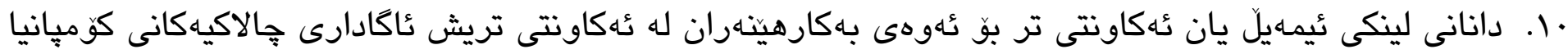

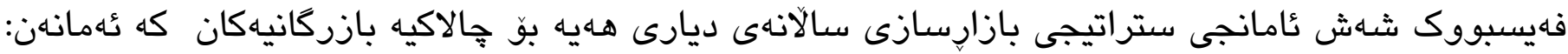
ا. بههيز كردن و بردودان و زيادكردن بوّ ناوه بازركانيهكهت (علامه التجاريه، Brand Awareness) Traffic زيادكردنى زمارهى سـهردانيكهرانى ويِبسايت ئهليكترونيهكهت Leads أبوكردنهوهى كاركهران C. زيادكردنى رِيّزهى ويِيبسايتكهت Conversions S. زيادكردنى رِيّزهى فروشتن Sales

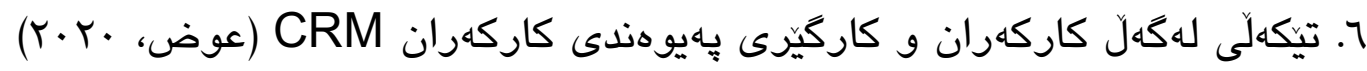

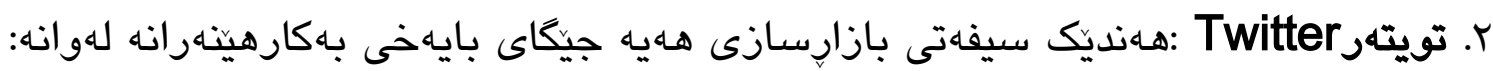

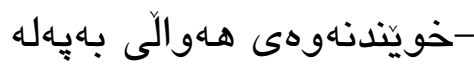
-زانينيى بيروكه و كارى كهسـهان -زانينى ثيهو دهنكدانهوانهى كه ميديا دروستى كردوه 


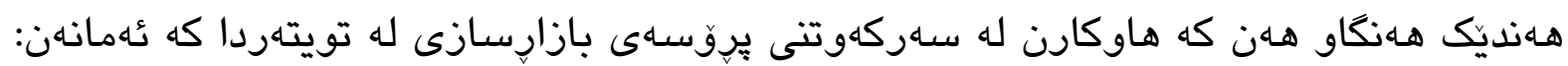

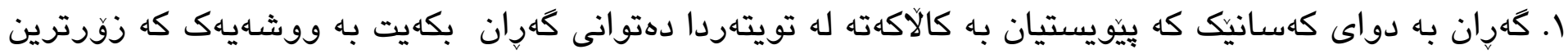

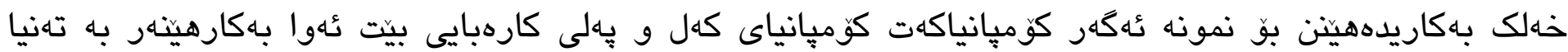

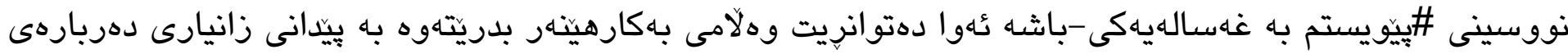

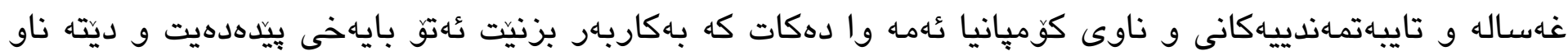

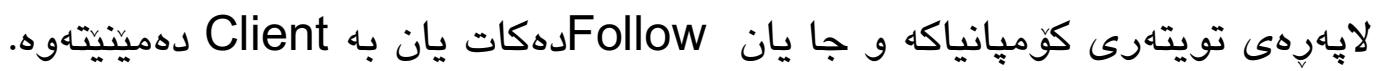

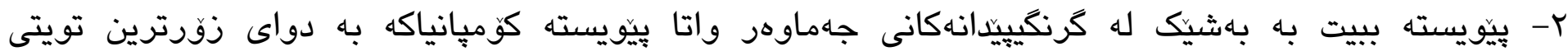

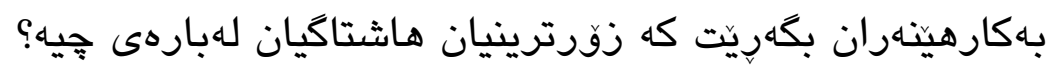

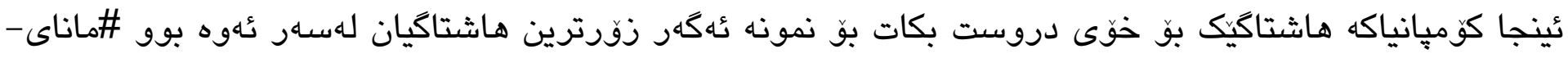

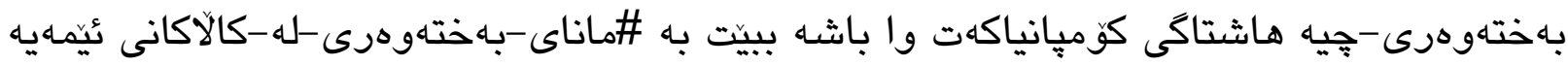

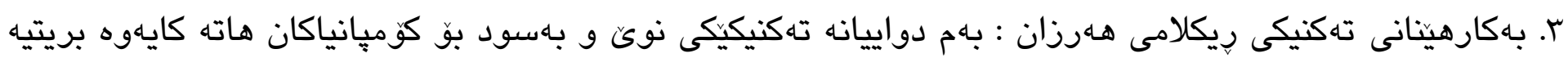

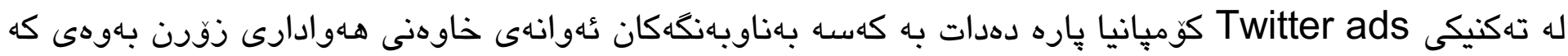

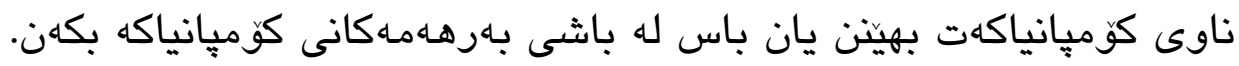

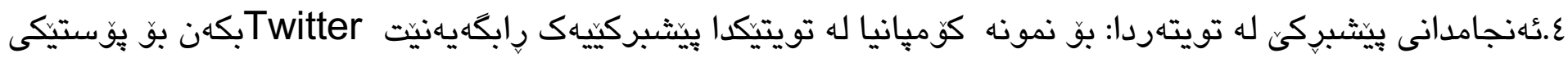

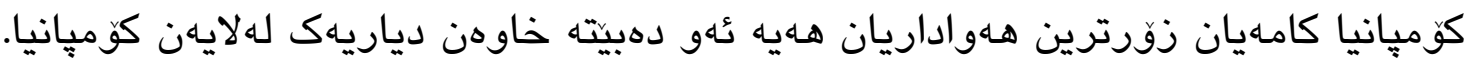

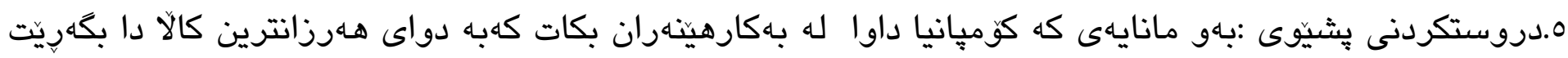

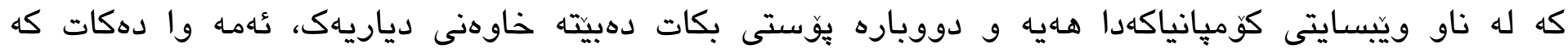

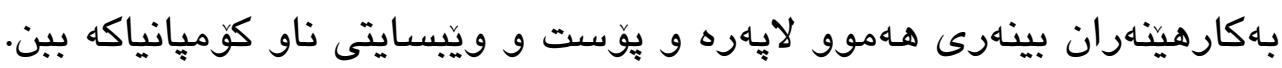

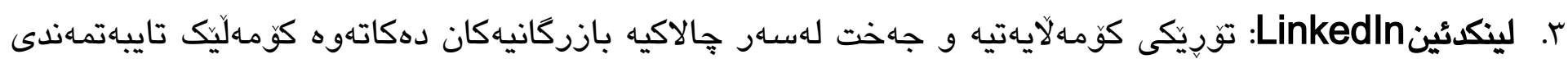
بازركانى هـيـه لهوانه:

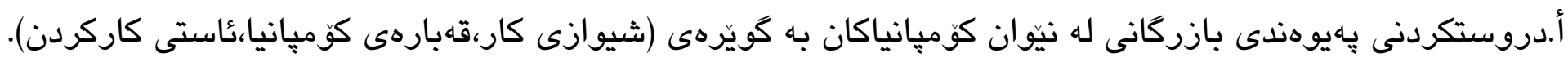

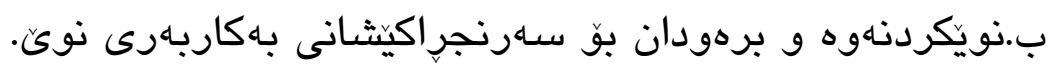
ج· ريكلامى دهقى و وينتاهيى.

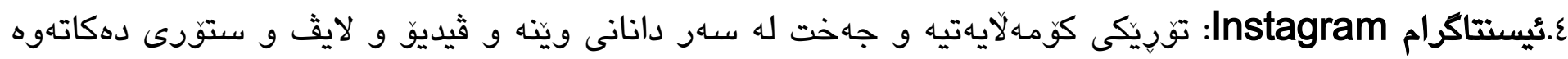

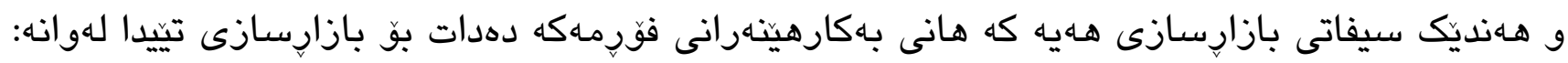
- بلاوكردنهوهى وينّه و ثيديوّ وهك جالاكيهكى كومـهلاِيهتى.

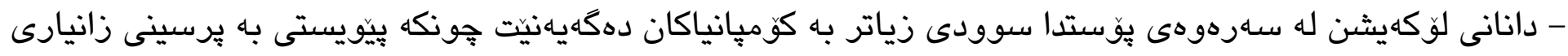

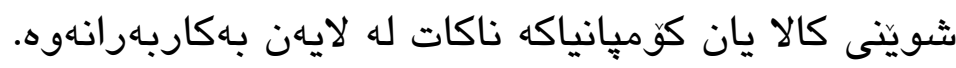

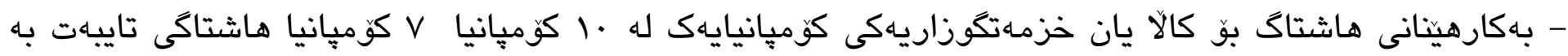
خُوى بهكاردههينيت بوّ بـهرهـاكاكانى. 
- بلاوكردنهوهى وينّه و ثيديق وهك جِالاكيهكى كومهلاًيهتى.

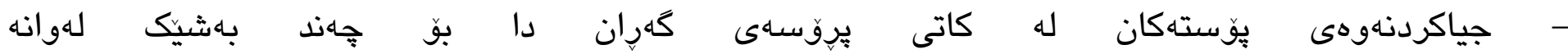
(IGTV,Shop,Travel,Architecture,Décor,Art,Food,Style,Tv.Movies,DIY0,Music,Sports,Beaut

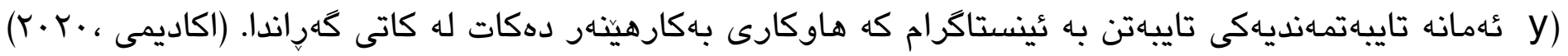

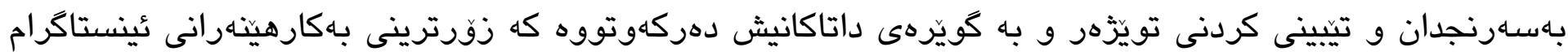

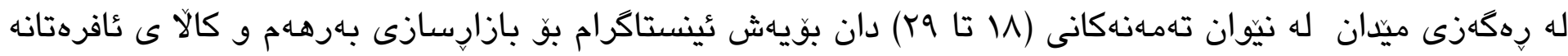

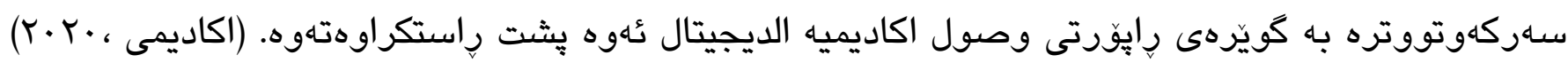

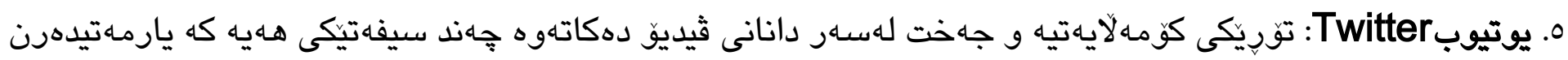

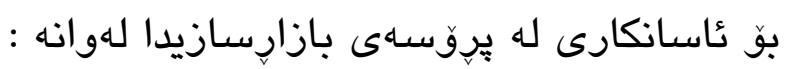

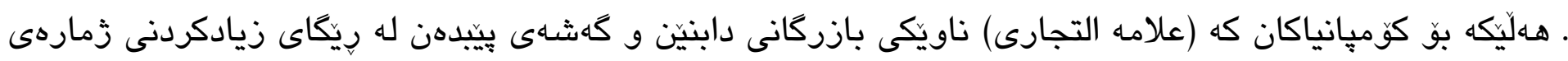
بهارهيناهران. - دانانى ريكلامى ثيديقى كورت و ناجينه كردنى.

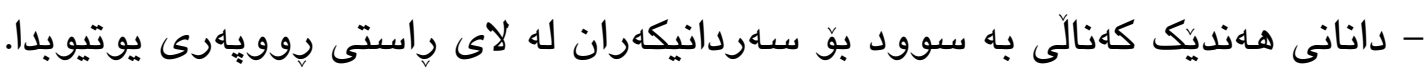

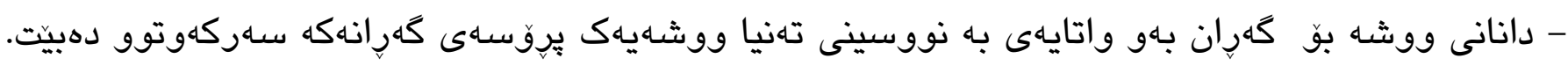

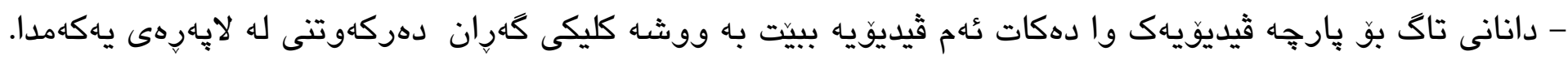

\section{دووهم: أنه يلِيكهيشنهكانى جات:}

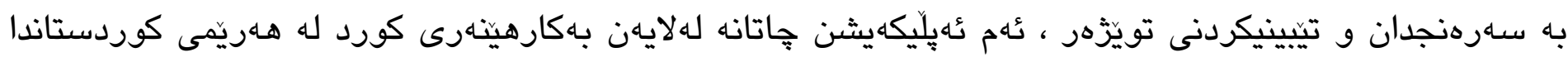

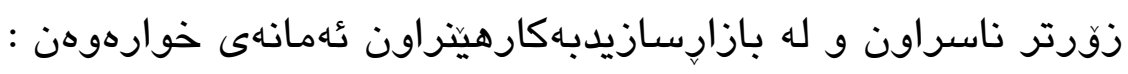

\section{Snapchat باتِ}

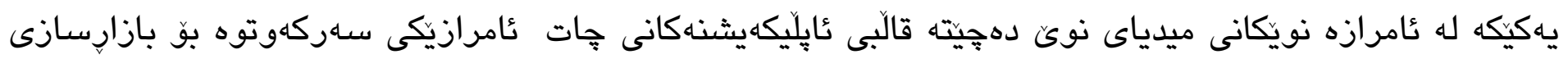

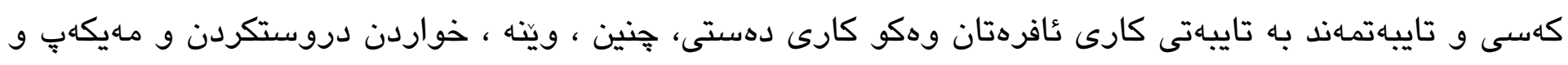

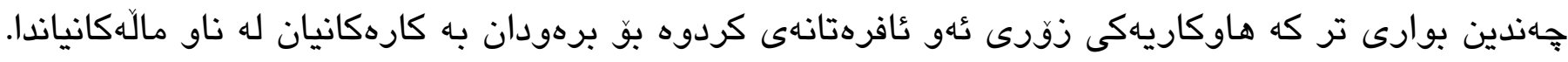

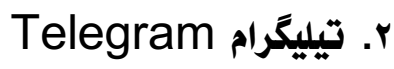

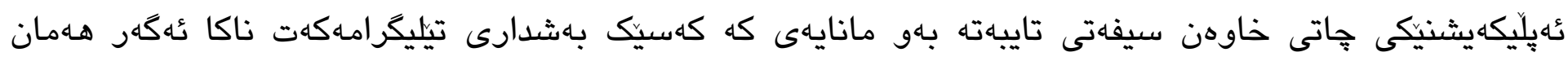

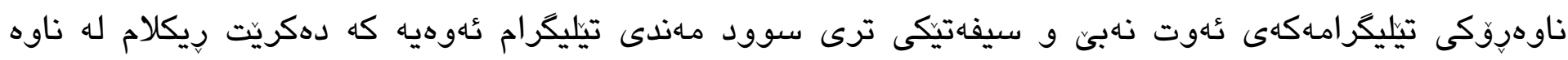

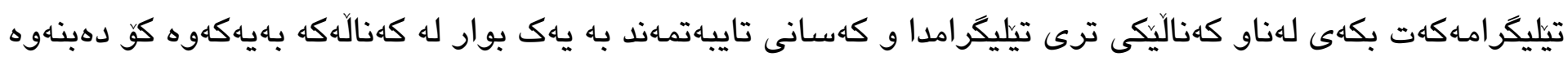

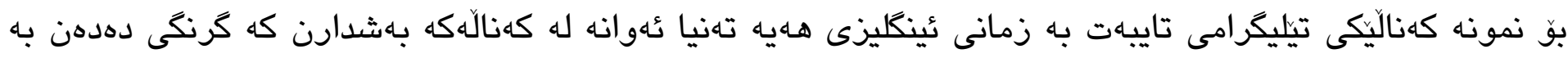
زمانى نينگليزى.

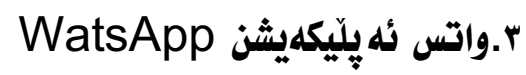




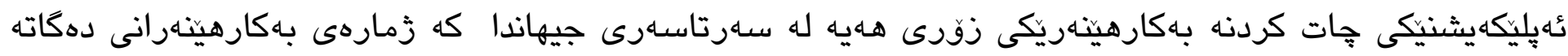

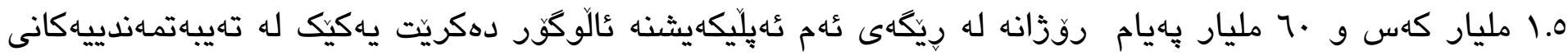

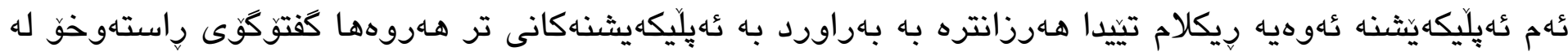

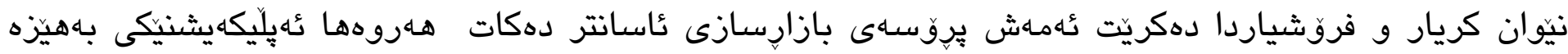

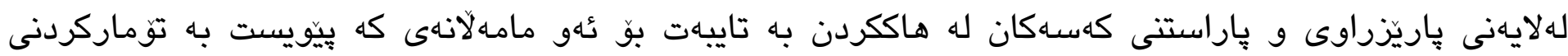

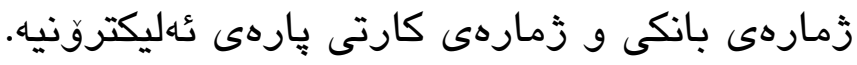

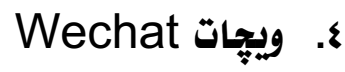

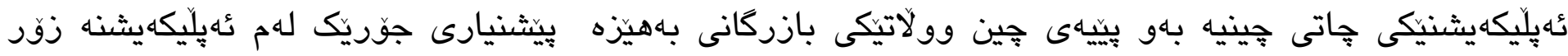

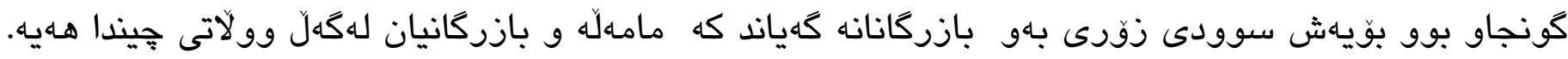

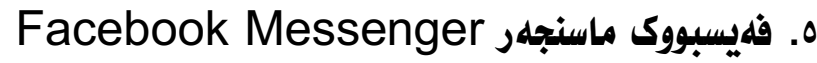

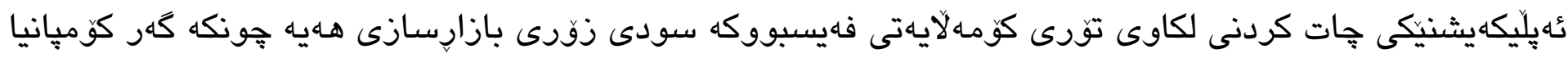

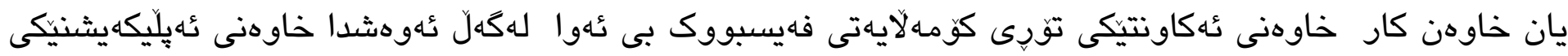

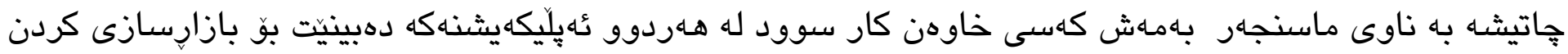

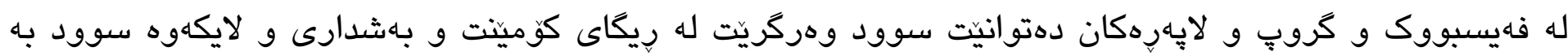

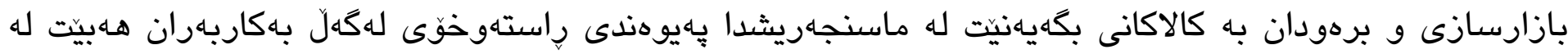

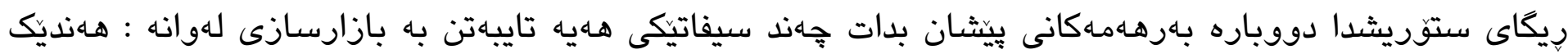

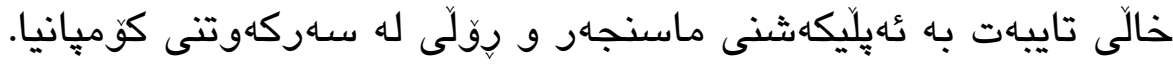

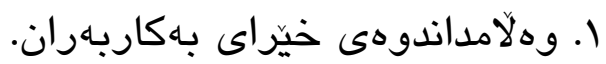

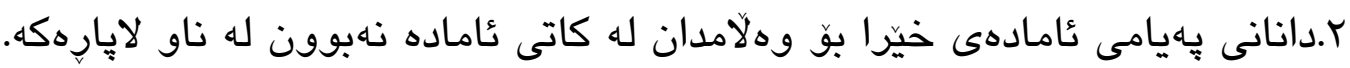
ז. دانانى يَهيامى كاتى كرانهوه و داخرانى كوميانيا و دواتر وهلاّم وهركرتن.

Viber

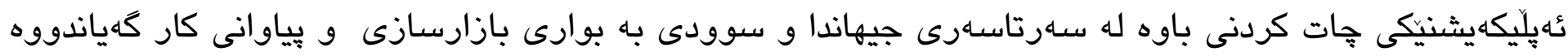

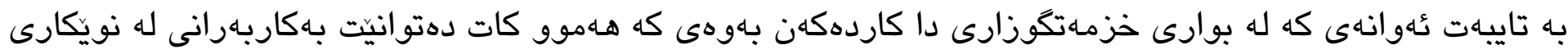

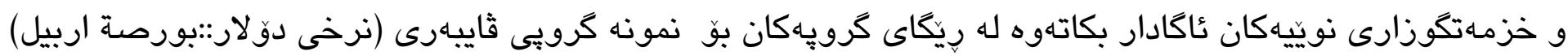

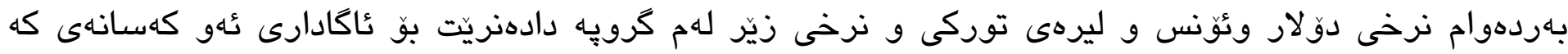

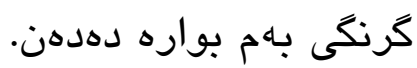

\section{Website ويّيَهم : ويّبسايت}

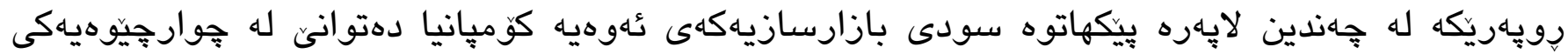
سنورداردا بازارسازى و برهودان بو كوميانياكان بكات واتا خزمهات به كيانيكى تايبهت دهكات بو نمونه ئهكَر 


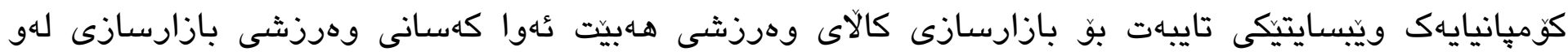
ويّيسايتها دهكهن و هـروهها بورياهي

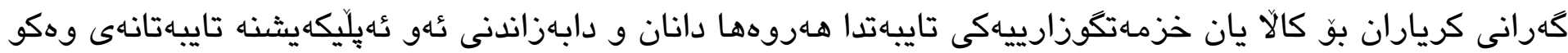

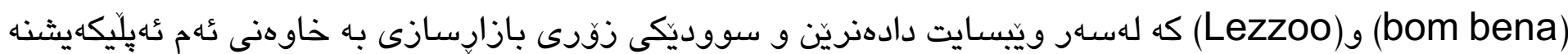
خوديانه كَهاندووه.

\section{توارهم: ئيهليّل E-mail}

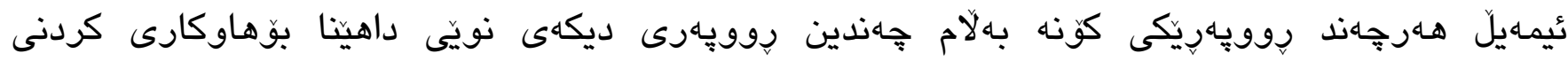

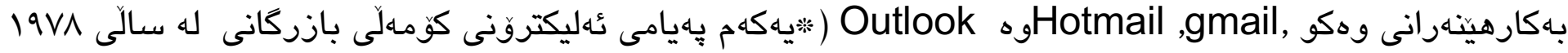

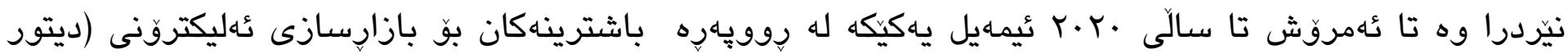
$(r \cdot r \cdot$.

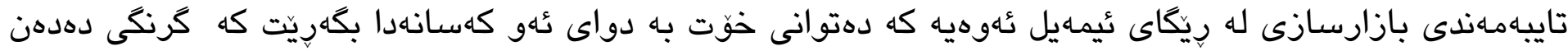

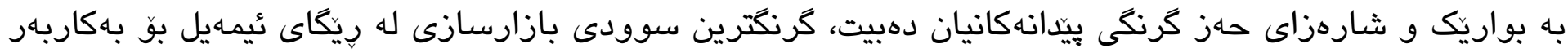

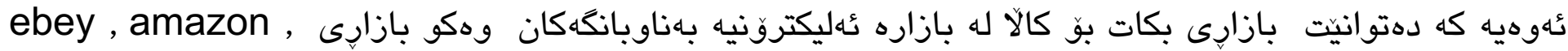
. alibaba

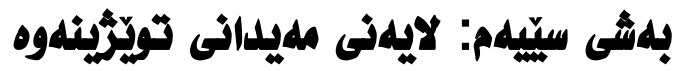

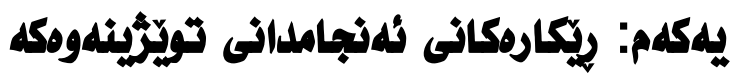

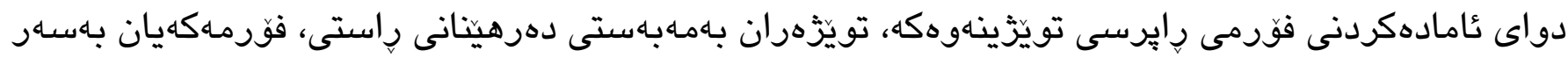

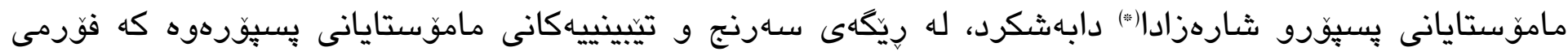

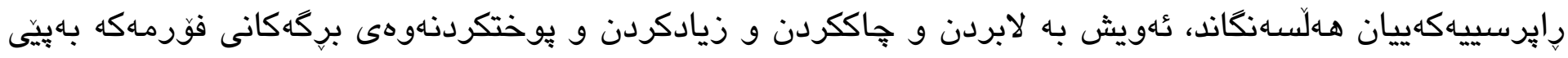

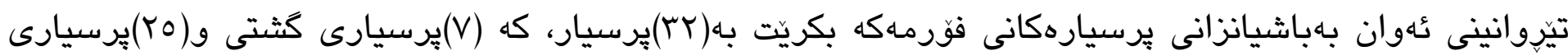

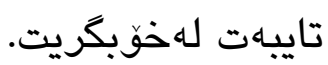

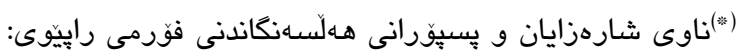

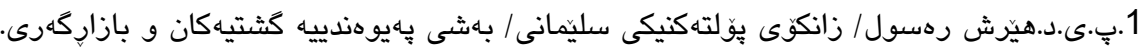
2.بْ.ى.د.حهبيب مال الله إبراهيم/ زانكوى دوّرتموّند له وولآتى ئهلمانيا/ بهشى رِاكهياندن. 3.ب.ى.د.رزكار مهذغديد ئهمده/ زانكوى سهلآحهدين/ بهشى عامار. 4.ب.ى.دئاراز رمضان احمد/ زانكوى رِإِرين/ بهريوهبهرايهتى رِاكهياندن. 5.ب..ى.د.سامى صابرعبدلله/ زانكوى سهلآحهدين/ بهشى كاركيزى بازاركهرى.

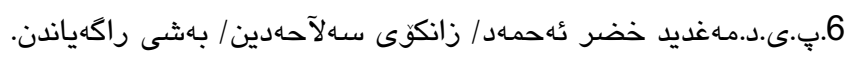




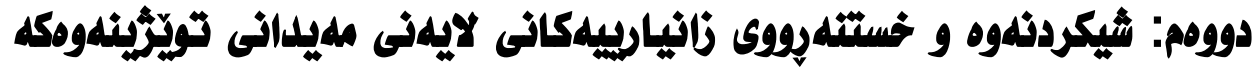

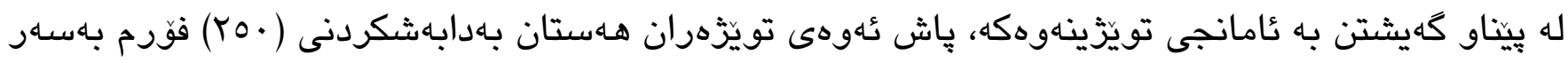

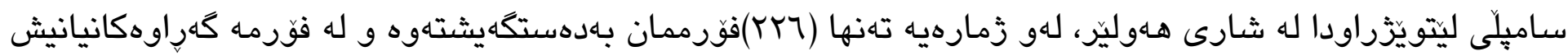

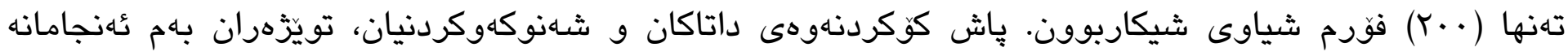
كهيشتن:

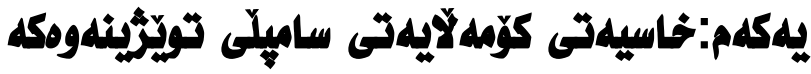

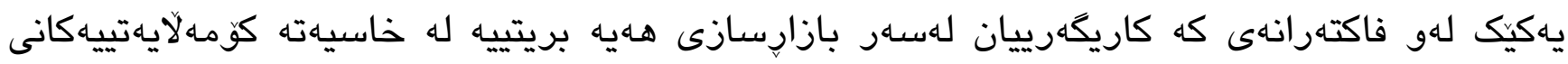
وهك: رهكَز، ئاستى خويتند،ئاستى زانيارى، بوّيه يهكيكه لهو بوارانهى كه تويّزهران له فوزرمى رايرسييهكهدا

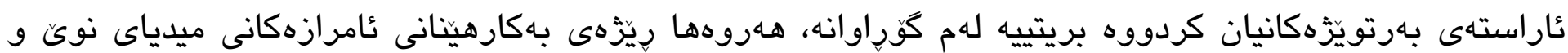

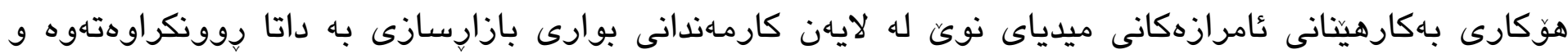

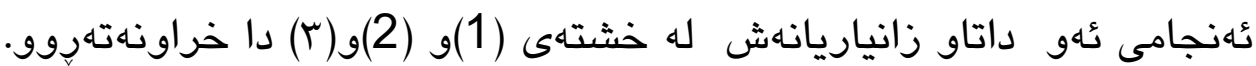

خشتهى(1) دابهشبوونى ساميلّى تويّزينهوه بهيّى رهكهز

\begin{tabular}{|c|c|c|}
\hline رِيّزههى سهدىى & زُماره & קهكهز \\
\hline $64.5 \%$ & 129 & نيّر \\
\hline $35.5 \%$ & 71 & مئى \\
\hline 100 & 200 & كوى كشتى \\
\hline
\end{tabular}

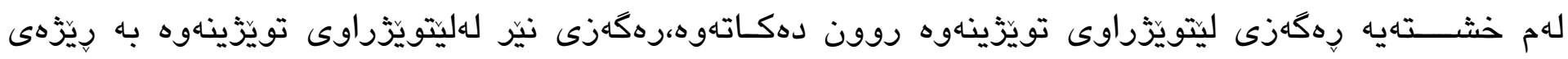

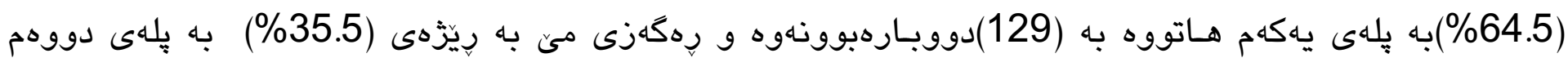

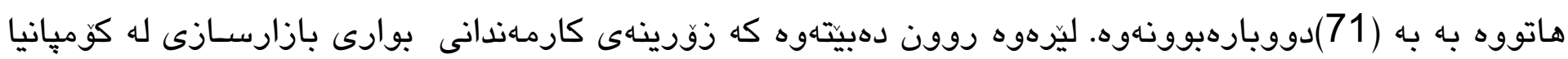

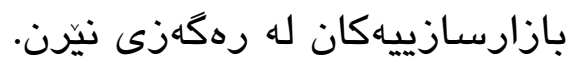

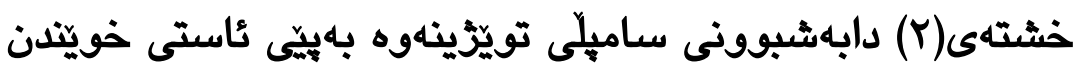

\begin{tabular}{|c|c|c|}
\hline رِيّزهى سـهدى & زُماره & دهستهوازه \\
\hline 10.5 & 21 & بنهرهتى \\
\hline $22.5 \%$ & 45 & ئامادهيى \\
\hline $16.0 \%$ & 32 & دبلوم \\
\hline $46.0 \%$ & 92 & بهكالوريوّس \\
\hline $1.0 \%$ & 2 & دبلومى بالاً \\
\hline $4.0 \%$ & 8 & ماستهر \\
\hline $0.0 \%$ & 0 & دكتورا \\
\hline 100 & 200 & كوى كشتى \\
\hline
\end{tabular}




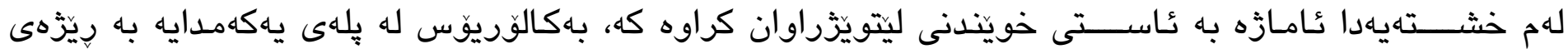

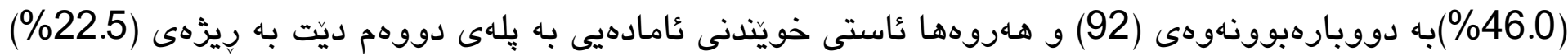

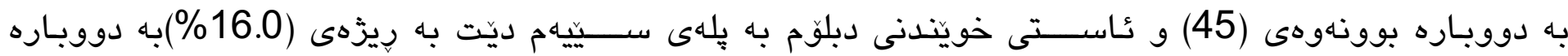

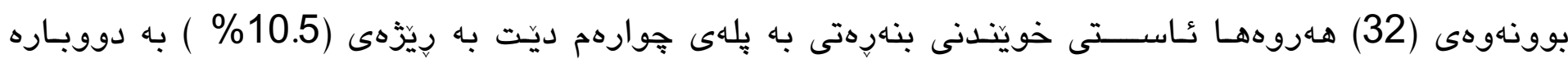

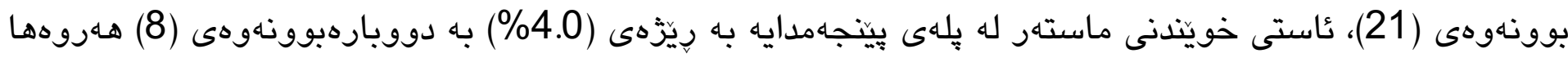

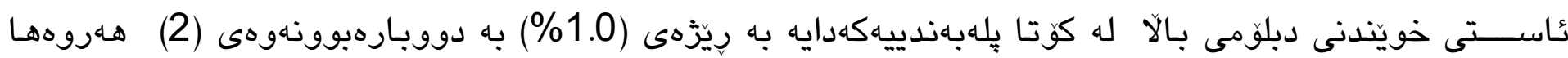

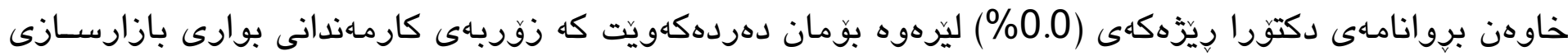

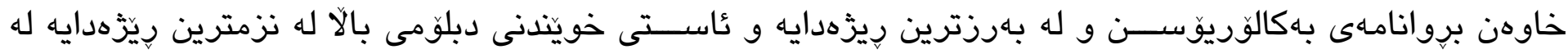

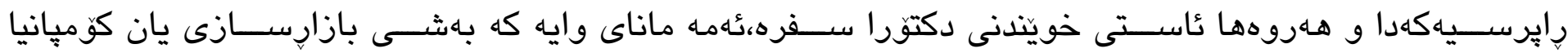

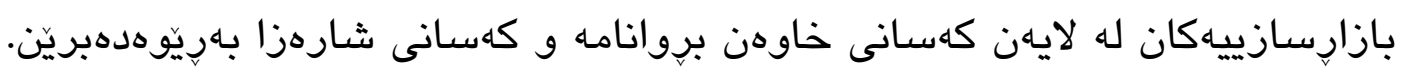

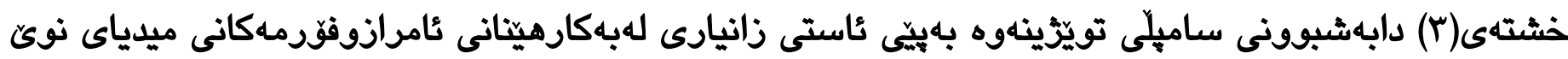

\begin{tabular}{|c|c|c|}
\hline رِيّزْى سهدىى & زُماره & تاست \\
\hline $51.5 \%$ & 103 & زقّد باش \\
\hline $42.5 \%$ & 85 & باش \\
\hline $1.0 \%$ & 2 & 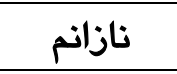 \\
\hline $5.0 \%$ & 10 & خراب \\
\hline $0.0 \%$ & 0 & زقد خراب \\
\hline 100 & 200 & كنى كشتى \\
\hline
\end{tabular}

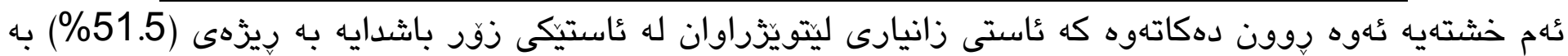

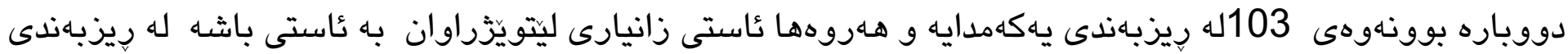

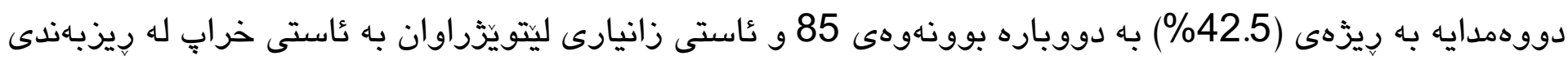

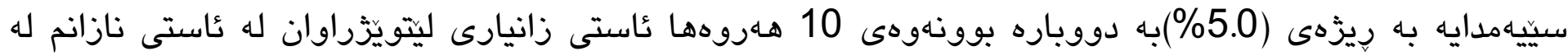

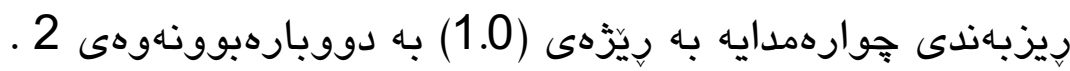

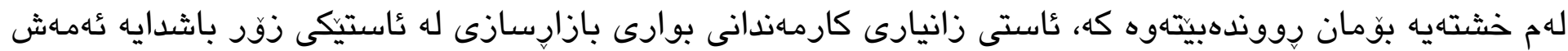

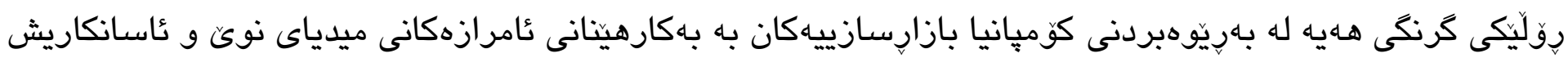
بوّ بـكاربهان.

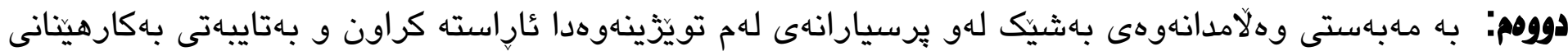

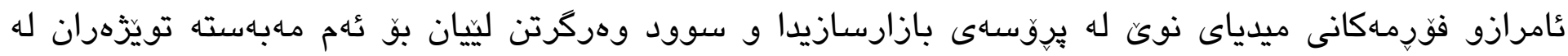

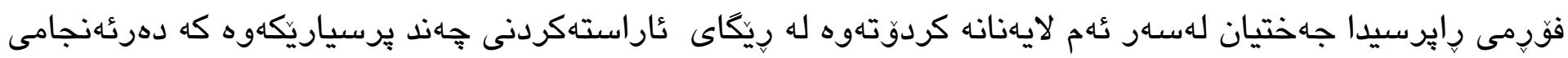

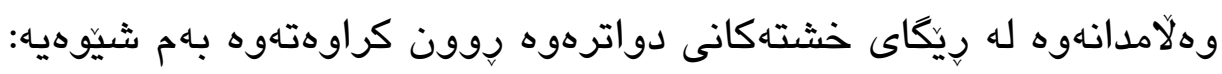


خشتهى (ع) بلهبهندى بهكارهينانى فؤرم و ثامرازهكانى ميدياى نوىيَ بو يروسهى بازارسازى

\begin{tabular}{|c|c|c|}
\hline ريّزّهى سهدىى & زماره & فورمهكانى ميدياى نوىى \\
\hline$\% 35.4$ & 173 & 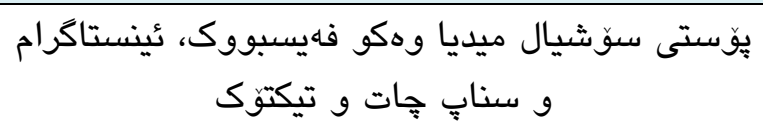 \\
\hline$\% 21.5$ & 105 & عُهيلِيكهيشن جاتهكانى وهك ثايبهر، واتسئاب، تيليكرام \\
\hline$\% 15.7$ & 77 & ئيمهيلّ ياخود مهايل كروب \\
\hline$\% 12.5$ & 61 & كروب ياخود يهيجى تقرهكومهلايهتييهكان \\
\hline$\% 8.4$ & 41 & ويّبسايت و بلوّك \\
\hline$\% 6.5$ & 32 & يوتيوب \\
\hline$\% 100.0$ & 489 & كوى كشتى \\
\hline
\end{tabular}

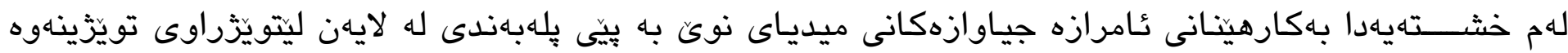

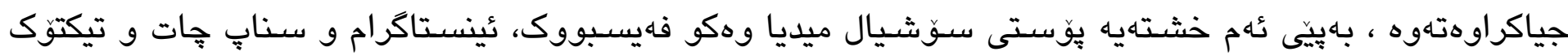

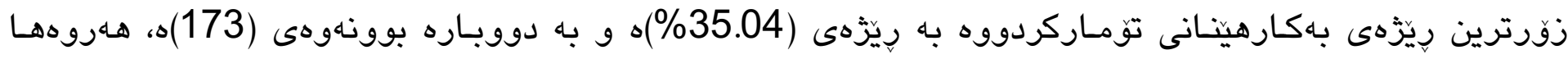

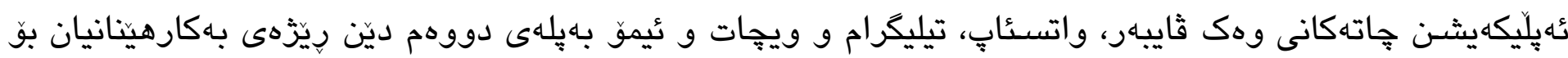

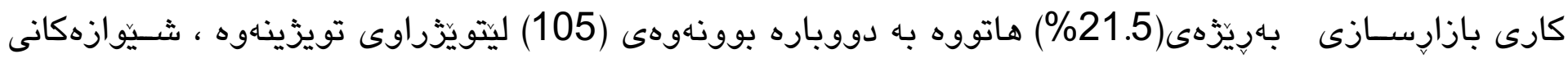

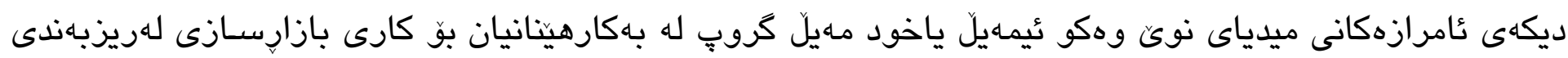

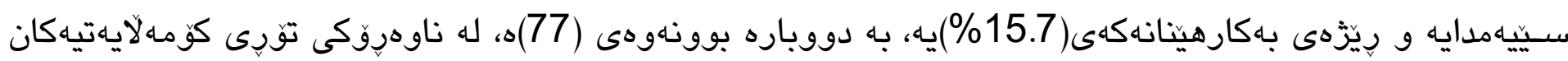

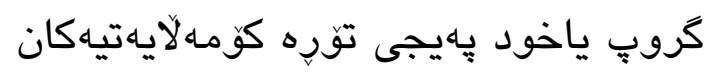

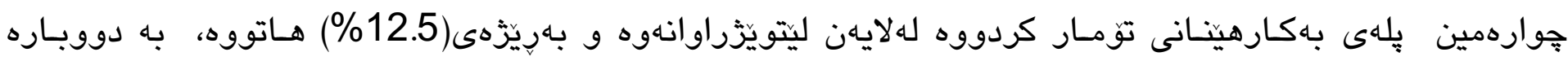

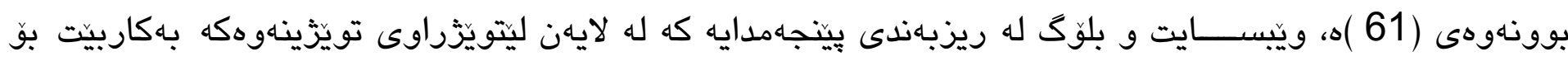

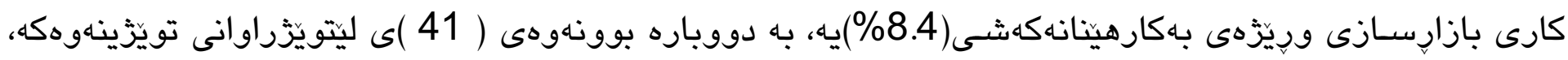

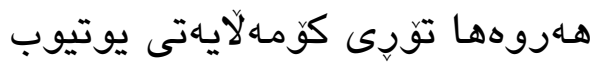

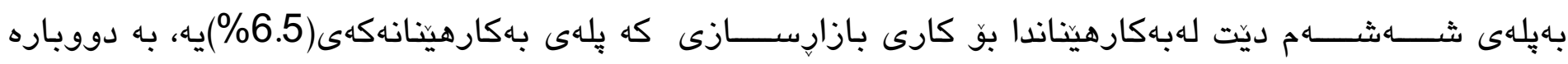
بوونهوهى (32 ).

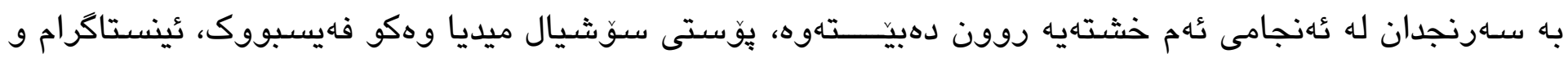

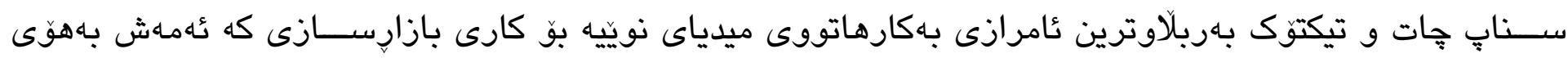

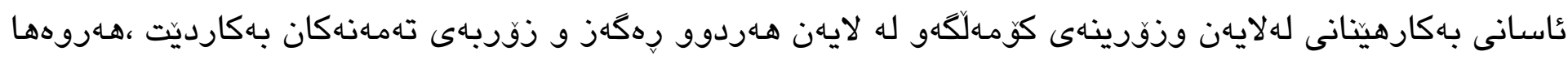

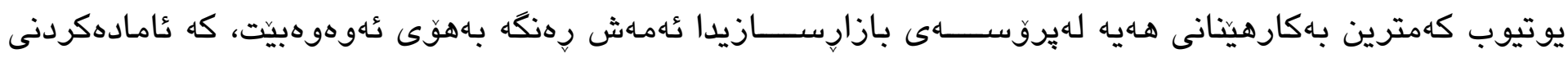

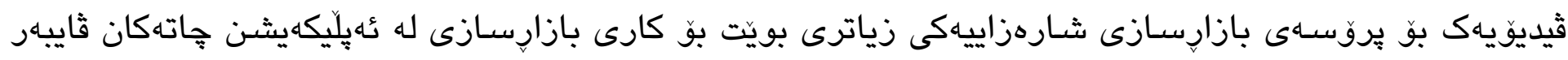

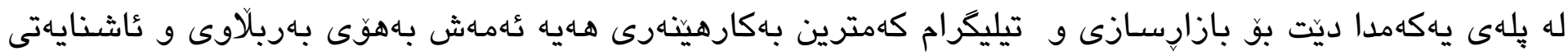




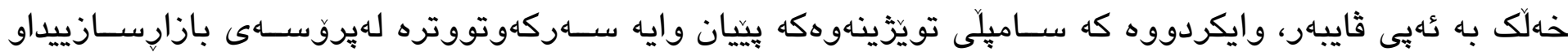

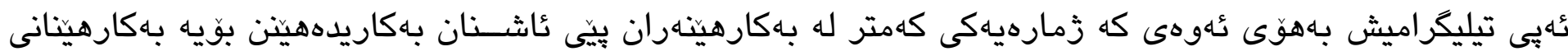

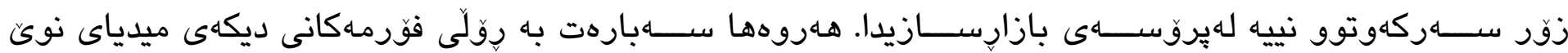

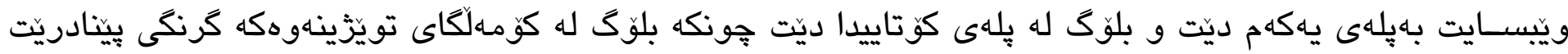
و خهلك زانياريان لهبارهيهوه نييه.

خشتهى(ه) ريّزّهى لهبارى بهكارهينانى ئامرازهانى ميدياى نويَ بو بازإسازى كالاو خزمهتكوزاريهكان קووندهكاتهوه

\begin{tabular}{|c|c|c|c|c|c|c|c|c|c|c|c|c|}
\hline 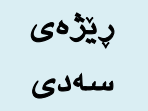 & لادانى & ناوهندى & هاورام & & مرام & & ل انم & & لرإنيم & & هيجي & \\
\hline هاورابوو & بيّوانهيى & رُميرّهيى & $\%$ & 3 & $\%$ & $j$ & $\%$ & 3 & $\%$ & $j$ & $\%$ & $j$ \\
\hline $80.10 \%$ & 0.77 & 4.01 & $21.5 \%$ & 43 & $65.0 \%$ & 130 & $6.5 \%$ & 13 & $6.5 \%$ & 13 & $0.5 \%$ & 1 \\
\hline
\end{tabular}

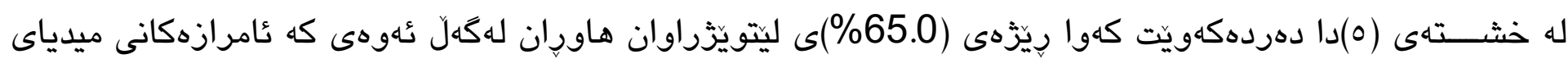

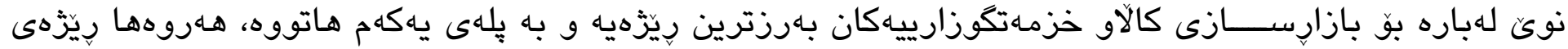

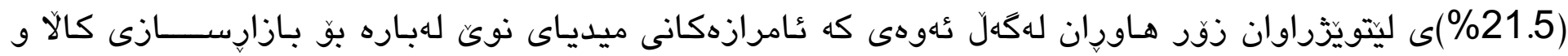

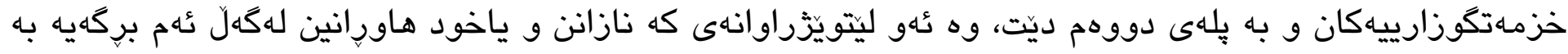

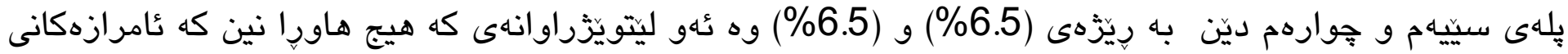

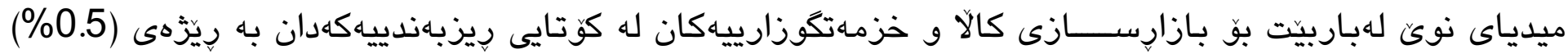

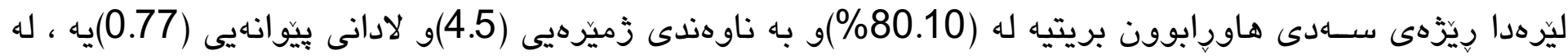

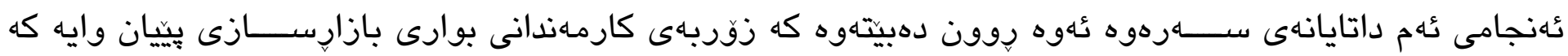

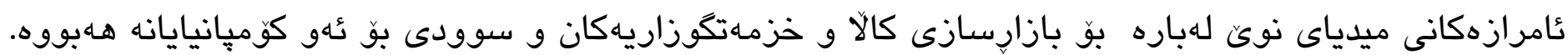

خشتهى (7)شيكردنهوهى بايوهندى(Correlation Analysis) نيوان كورياوه بنهرهتييكانى تويزينهوهكه

\begin{tabular}{|c|c|c|}
\hline ئامرازهكانى ميدياى نوىن & 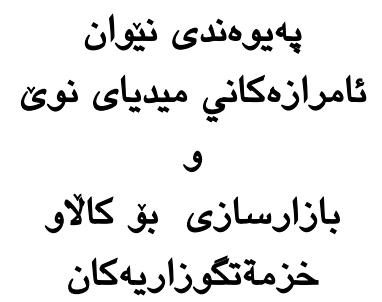 & و بازارسازى بّ كالآ \\
\hline $0.207^{\star *}$ & & Pearson Correlation \\
\hline 0.003 & & Sig. (2-tailed) \\
\hline 200 & & $\mathrm{~N}$ \\
\hline
\end{tabular}




\section{**. Correlation is significant at the 0.01 level (2-tailed).}

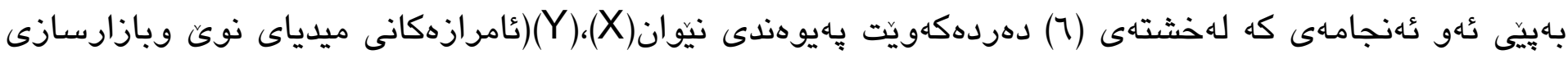

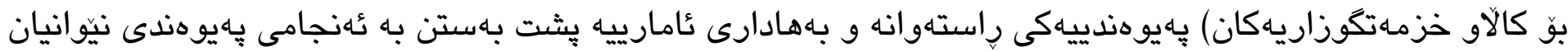

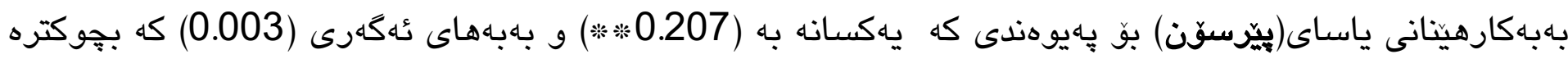

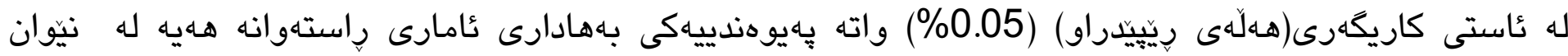

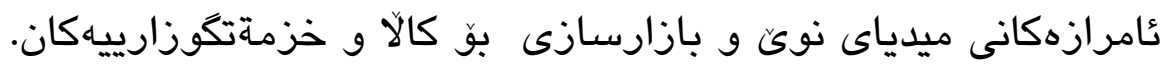

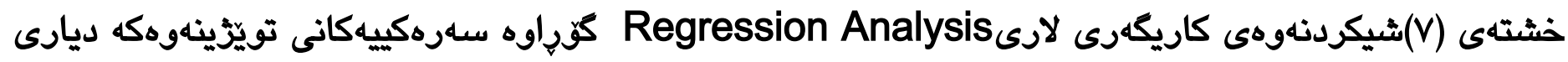
دهكات

\begin{tabular}{|c|c|c|c|c|c|c|}
\hline & \multicolumn{5}{|c|}{ Model Summary } \\
\hline & & \multirow{2}{*}{$\begin{array}{c}\text { Std. Error of } \\
\text { the Estimate } \\
0.75943\end{array}$} & \multirow{2}{*}{$\begin{array}{c}\text { Adjusted } \\
\text { R } \\
\text { Square } \\
0.038\end{array}$} & $\begin{array}{c}\mathrm{R} \\
\text { Square }\end{array}$ & $\mathrm{R}$ & Model \\
\hline & & & & 0.043 & $.207^{a}$ & 1 \\
\hline & & \multirow{2}{*}{\multicolumn{5}{|c|}{$\begin{array}{l}\text { a. Predictors: (Constant), عامرازهكانى ميدياى نوى } \\
\text { ANOVA }^{a}\end{array}$}} \\
\hline & & & & & & \\
\hline Sig. & $F$ & Mean Square & Df & $\begin{array}{l}\text { Sum of } \\
\text { Squares }\end{array}$ & \multicolumn{2}{|c|}{ Model } \\
\hline \multirow{3}{*}{$.003^{\mathrm{b}}$} & \multirow[t]{3}{*}{8.845} & 5.101 & 1 & 5.101 & Regression & \multirow{3}{*}{1} \\
\hline & & 0.577 & 198 & 114.193 & Residual & \\
\hline & & & 199 & 119.294 & Total & \\
\hline \multicolumn{7}{|c|}{ 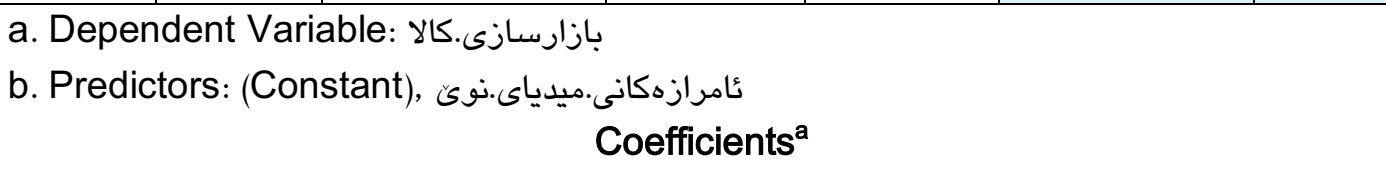 } \\
\hline \multirow[t]{2}{*}{ Sig. } & \multirow[t]{2}{*}{$\mathrm{T}$} & $\begin{array}{l}\text { Standardized } \\
\text { Coefficients }\end{array}$ & \multicolumn{2}{|c|}{$\begin{array}{l}\text { Unstandardized } \\
\text { Coefficients }\end{array}$} & \multirow{2}{*}{\multicolumn{2}{|c|}{ Model }} \\
\hline & & Beta & Std. Error & B & & \\
\hline 0.000 & 20.720 & & 0.320 & 6.638 & (Constant) & \\
\hline 0.003 & 2.974 & 0.207 & 0.072 & 0.213 & ميدامرازهانى نوىى & 1 \\
\hline
\end{tabular}

a. Dependent Variable: بازارسازى.كالا

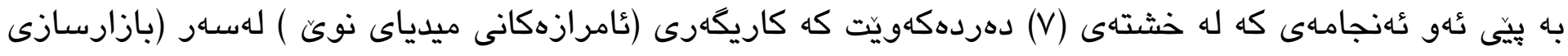

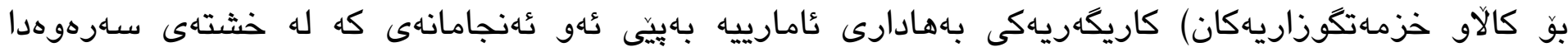
روونكراوهتهوه، له خشتهى (Model Summary) نرخى(

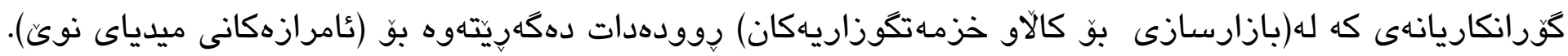




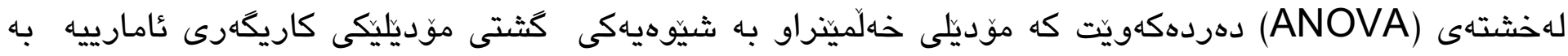

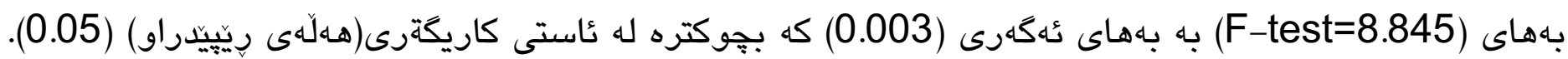

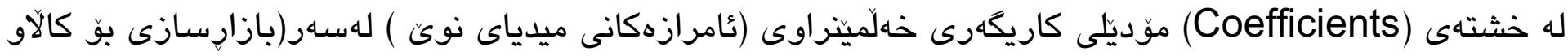
خزمهتكوزارييهكان) كه دهتوانين بهو هاوكيشاهيه بينووسين.

$Y=6.638+0.213 * X$

Y=)

X=(ئمرازهكانى ميدياى نوين)

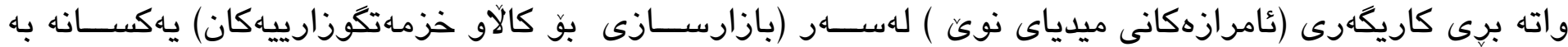

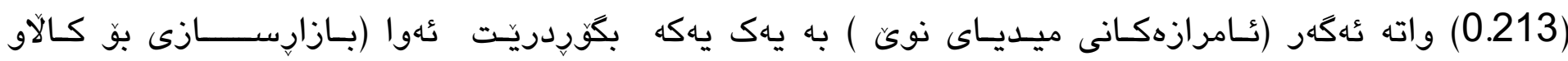

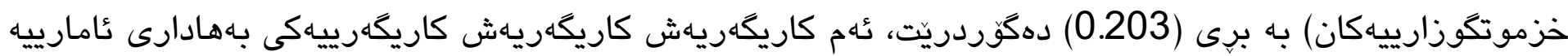

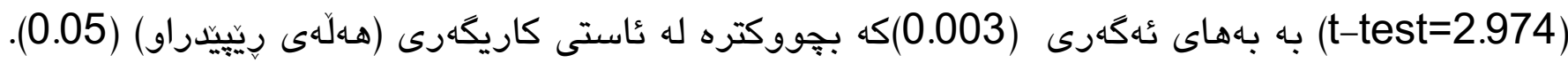

\section{دمرئلهزجامهكان}

دواى كوكردنهوهو خستنهوووى داتاو زانيارييهكان و شيكردنهوهى خشتهانى تويَّزينهوهك لهكوتايى

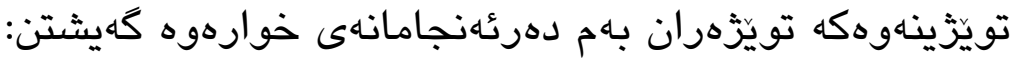

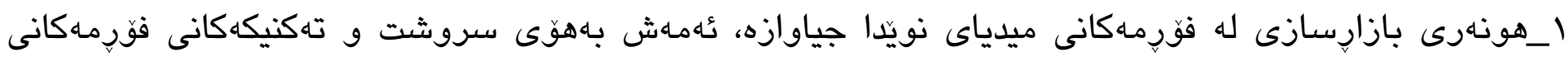

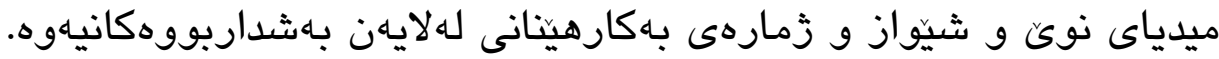

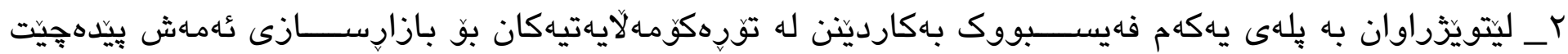

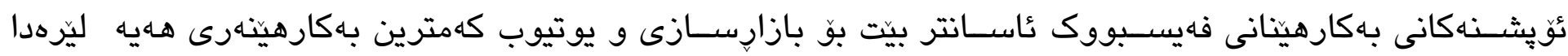

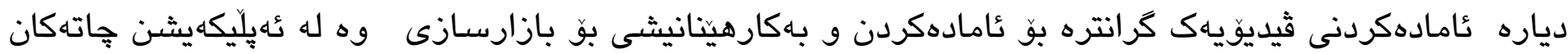

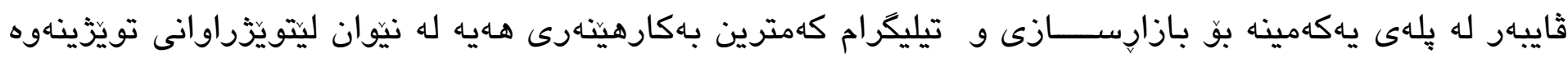

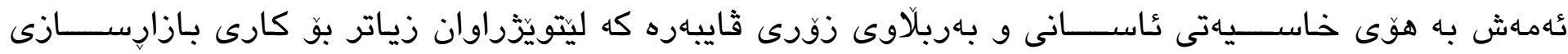

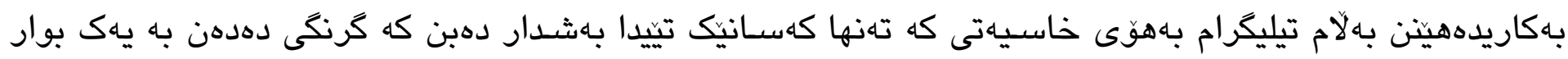

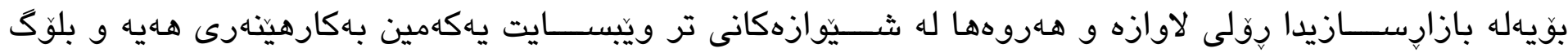

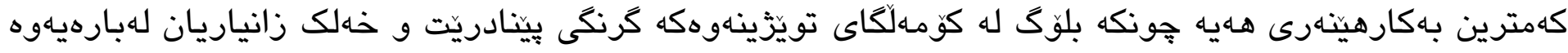

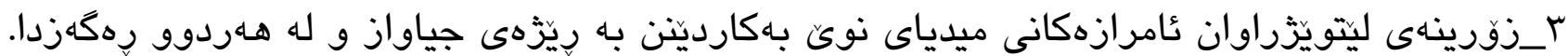

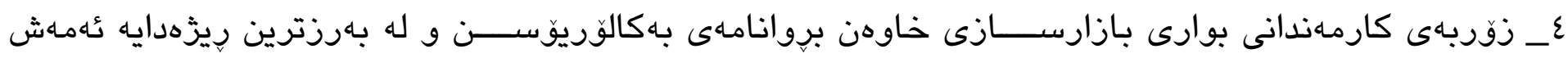

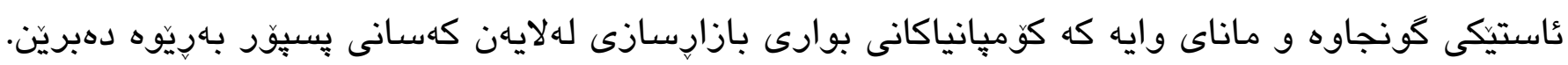




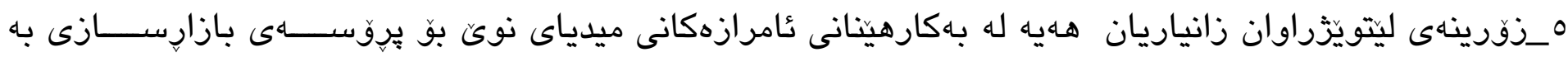
ئاستى جياواز.

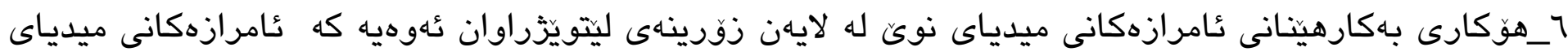

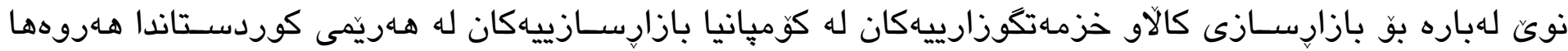

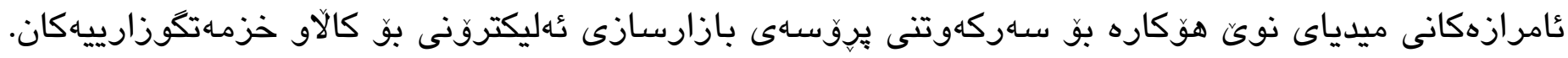

\section{بي}

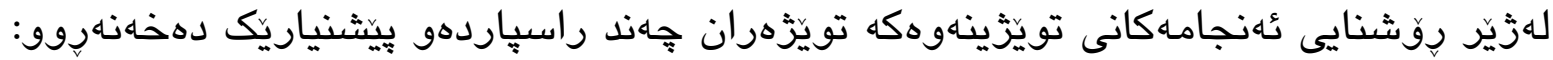

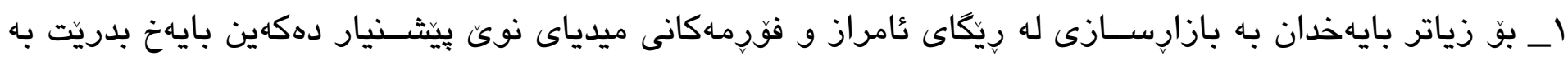

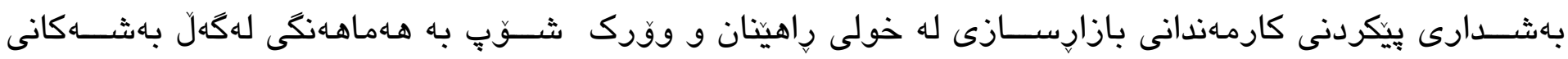

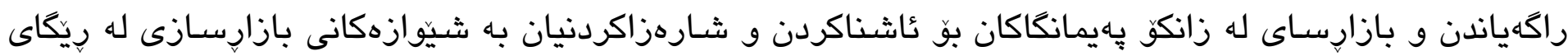

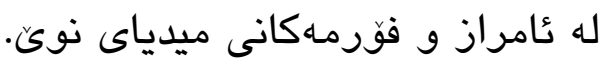

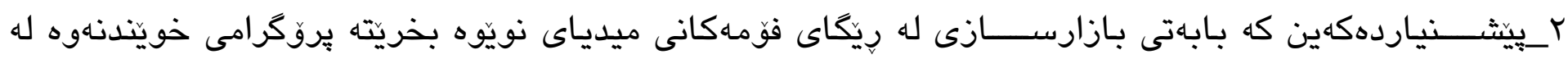
بهاهـانى راكهياندن و كاركيزّى كار دا.

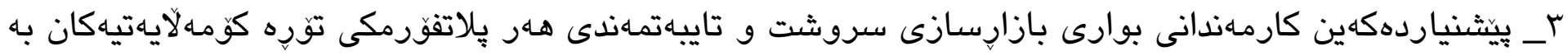

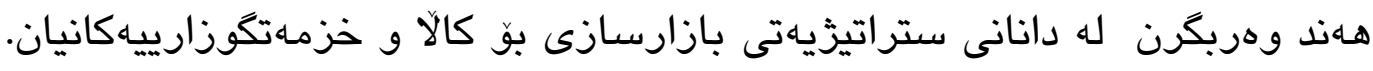
عـ يِيشنياردهكهين تويَزَينهوهى ووردتر و فراوانتر بكريّت له بوارى بازارسازى له ئامرازهانى ميدياى نويدّا. 


\title{
The Role of New Media Tools in Marketing for Goods and Services
}

\author{
Parwa Omer Mahmud \\ Department of Media, College of Arts, Salahaddin University, Erbil, Kurdistan Region, Iraq. \\ E-mail: perwa.umer@yahoo.com
}

\section{Hardwan Mahmud Kaka Shekh}

Department of Media, College of Arts, Salahaddin University, Erbil, Kurdistan Region, Iraq.

E-mail: hardawan@su.edu.krd

\begin{abstract}
:
This research is an attempt to determine the role of new media tools in marketing for goods and services through a sample of marketing companies for goods and services. This research refers to the way marketing and electronic marketing equipment are used, and the most used marketing tools in the Kurdistan Region are.

The most important outcomes researchers have received are the art of marketing in new media forms, due to the nature and technique of new media forms and the number of use by participants. According to the majority of Facebook research samples, it comes in the first rank in the marketing process for services and this seems to be because the number of Facebook users is higher than any other network Facebook's options and usage options are also easier to market and the YouTweed social network has the least use in the marketing process, which may be because of it, which would make it more skilled to prepare a video for the marketing process. In the app chats, Viber comes first to marketing and telegram has the least users, and this is because of the wide and familiarity of people with App Viber, which the research samples believe It is more successful in the marketing process and the app ity of the architecture is because a small number of users are familiar with it, so it is not very successful in the marketing process. Also, about the role of new media forms, the website comes in the first place and the blog comes in the rank of co-coordinator because the blog in the research community is not cared for and people don't have information about it.
\end{abstract}

Keywords: New Media, New Media Tools, Marketing, Marketing in New Media Tools, Goods, Services. 


\section{سلورجاومكان}

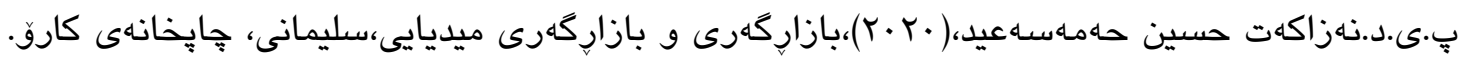

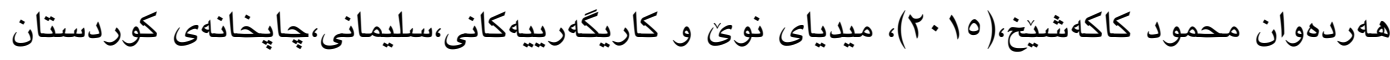
بخوش ايمان, مرزقي حسام الدين.(9...) الويب 2.0 الاشبكات الاجتماعية و الاعلام الجديد.

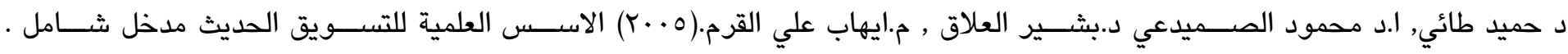
الجزائر:دار اليازوري

د.احمد بدر،(ع -r) اصول البحث العلمي و مناهجه. الدوحة: المكتبة الاكادميةabcd

د.اياد عبدالفتاح النسور و د.عبدالرحمن عبدالله الصغير. (عا.ب)قضـايا ة تطبيقات تسـويقية معصـاصـرة ـ الرياض : دار صفاء للنشـر و التوزيع.

د.شرين أبو وردة.(7 ·r)التسويق المستندام ـ مصر : دار تنوير للنشر و التوزيع.

د.محمد خليل الرفاعى.(1) (Y) دور الاعلام فى العصر الرقمى فى القيم الاسرة العربيه . دمشق : مجله العربيه الدمشق.

دكتور سعيد البطوطي. (Y ·ץ)التسويق السياحي. مصر : المكتبة انجلو المصرية.

رولا عبدالرحمن الجمل.(9..+). الاعلام الجديد :التكنولوجيا جديدة:العالم الجديد. مملكة البحرين: ابحاث المؤتمر الدولي,جامعة البحرين.

د.زكريا احمد عزام،د.عبدالباسط حسونه،دمصطفى سعيد. (9.ب)مبادئ التسويق الحديث بين النظرية و التطبيق. عمان: دار الميسرة. نبيل الحورة.(10 - إ) اتجاهات الاساتذة الجامعيين الجزائريين نحو دور الاعلام الجديد في التشغيل الوعي المعلوماتي. مصر.

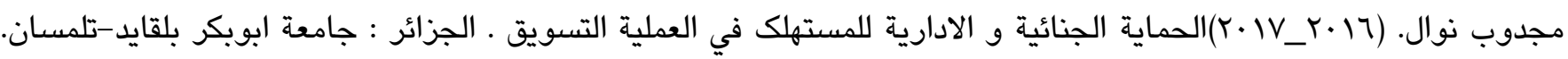




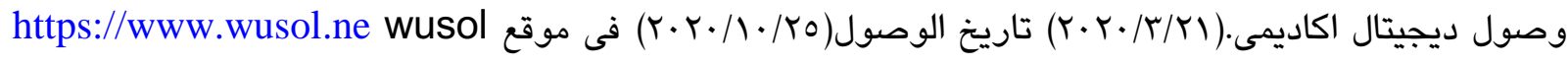

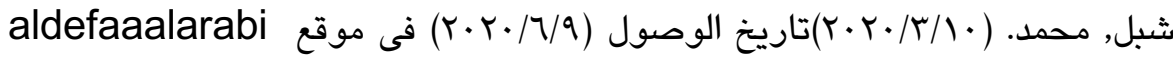
http://www.aldefaaalarabi.com

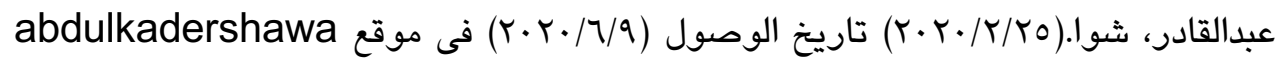
https://www.abdulkadershawa.com

ع.نعمة، محمود.(Y/9/T) تاريخ وصول (Y.Y./T/9) فى موقع akwadna)

Hardwick, J.(18,5,2020) Retrieved 11,6,2020 from ahrefs bloge

https://ahrefs.com/blog/what-is-seo.

Matisse,M.( 23,11,2019) Retrieved 9,6,2020 from matisse

https://matissedm.com 